\title{
AÇÕES DE REINTEGRAÇÃO DE POSSE CONTRA O MOVIMENTO DOS TRABALHADORES SEM TETO: DICOTOMIA ENTRE PROPRIEDADE E DIREITO À MORADIA.
}

\section{ACTIONS OF REINTEGRATION OF POSSESSION AGAINST THE MOVEMENT OF HOMELESS WORKERS: DICHOTOMY BETWEEN PROPERTY AND RIGHT TO HOUSING.}

\author{
Alexandre Bernardino Costa ${ }^{1}$ \\ Rafael de Acypreste ${ }^{2}$
}

De todas as coisas seguras, a mais segura é a dúvida.

Bertolt Brecht

\section{Resumo}

Nas ações de reintegração de posse contra o Movimento dos Trabalhadores Sem Teto (MTST), a propriedade é o elemento central de proteção do Poder Judiciário. O objetivo do trabalho é analisar a forma como o Poder Judiciário lida com conflitos fundiários urbanos dos quais faz parte o referido Movimento Social. A partir da teoria fundamentada nos dados, analisa-se todas as ações de reintegração de posse contra o MTST de 2001 a 2014. Essa metodologia permite identificar propriedades, dimensões, minúcias e singularidades das decisões com base em comparações sistemáticas entre os dados. A literatura jurídica levantada e o referencial teórico têm por base a identificação da categoria chave explicativa do conjunto dos dados. Como resultado, percebeu-se que a proteção da propriedade absoluta é o fundamento principal dos magistrados nas ações de reintegração de posse. As categorias constitucionais do direito à moradia e da função social da propriedade são pouco exploradas pelos juízes. Há, também, inconsistências processuais nas decisões e baixa preocupação com a fundamentação fática e jurídica da posse exercida pelos proprietários. Conclui-se que o Poder Judiciário, em relação ao objeto de análise, desconsidera o interesse social subjacente aos processos, para proteger a propriedade em seu formato liberal e absoluto.

Palavras-chave: Direito à moradia. Função Social da Propriedade. Propriedade. Movimento Social Urbano. Poder Judiciário.

\begin{abstract}
In repossession actions against the Movimento dos Trabalhadores Sem Teto (Homeless Workers Movement - MTST in portuguese), the property is the central element of the judiciary protection. The objective is to analyze how the judiciary handles urban land conflicts of which is part of said Movement Social. From the grounded theory, this paper analyzes all reintegration actions of possession against MTST since 2001 to 2014. This methodology allows us to identify properties, dimensions, minutiae and singularities of decisions based on systematic comparisons between the

\footnotetext{
${ }^{1}$ Doutor em Direito em Constitucional pela Universidade Federal de Minas Gerais. Professor adjunto da Faculdade de Direito da Universidade de Brasília. E-mail: abc.alexandre@gmail.com

2 Mestre em Direito pela Universidade de Brasília. Professor do Instituto de Ensino Superior Planalto IESPLAN. E-mail: rafaeldeacyprestemr@gmail.com
} 
data. The legal literature raised and the theoretical framework are based on the identification of key explanatory category of all data. As a result, it was realized that the property protection is the main foundation of the magistrates in repossession actions. The constitutional categories of housing rights and the social function of property are little explored by the judges. There are also procedural inconsistencies in decisions and low concern about the factual and legal basis of ownership exercised by the owners. We conclude that the judiciary, in relation to the object of analysis, ignores the underlying social interest in their cases to protect property in its liberal and absolute format.

Keywords: Right to housing. Social Function of the Property. Property. Urban Social Movement. Judicial Power. 


\section{INTRODUÇÃO}

O presente artigo surge das reflexões acerca do trabalho de dissertação de Mestrado em Direito do primeiro autor, sob orientação do segundo autor. O estudo buscou analisar, empiricamente, a partir de decisões judiciais, a maneira com que o Poder Judiciário enfrenta os conflitos fundiários urbanos por moradia levados a cabo pelo Movimento dos Trabalhadores Sem Teto (MTST). Com isso, coletaram-se todas as decisões de reintegração de posse contra o MTST nos Estados em que este se faz presente, no período de 2001 (marco da promulgação do Estatuto da Cidade) a 2014.

O trabalho surge a partir da avaliação de que a ação de reintegração de posse configura-se como instrumento jurídico e político utilizado, por excelência, pelos proprietários formais de imóveis ocupados por movimentos sociais urbanos. Em geral, são ocupados imóveis com duas finalidades: denúncia da demanda por moradia em sentido amplo ou para exposição pública do não cumprimento da função social da propriedade em determinado terreno. Nesse sentido, o Poder Judiciário se torna palco principal de resolução de tal conflito, sendo instado a decidir o caso, dentro de suas competências e a despeito de suas limitações. O tema central no debate jurídico gira em torno da contradição entre direito de propriedade, de um lado, e direito à moradia, de outro.

A presente pesquisa também foi elaborada no sentido de dialogar com pesquisas semelhantes realizadas com base em estudos sobre ações de reintegração de posse. (ABREU, 2011, 2014; DANTAS, 2013; FROTA, 2015; SAULE JÚNIOR; LIBÓRIO; AURELLI, 2009; SCHREIBER, 2000). O que se pretende no presente artigo é se concentrar em descrever e analisar a prática decisória do Poder Judiciário relativa ao conflito entre proprietário e um movimento social urbano. A partir deste, está representado o cerne político da demanda por direito à moradia originado de uma ação direta de uma organização social. Para isso, a partir da metodologia adotada, busca-se extrair dos dados o que há de padrão e de baliza para essa mesma prática decisória no contexto de atuação do Movimento dos Trabalhadores Sem Teto (MTST).

Num primeiro momento, avalia-se que a cidade constitui complexo objeto de estudo e que esta pesquisa apresenta um esforço nesse sentido, a partir do campo de visão do Direito, mas em diálogo com outros campos do conhecimento. Henri Lefebvre, referência para os estudos de direito 
à cidade, reconhece esse tema com um caráter de totalidade altamente complexo, "simultaneamente em ato e em potencial, que visa à pesquisa, que se descobre pouco a pouco, que só se esgotará lentamente e mesmo nunca, talvez" (LEFEBVRE, 2008, p. 111). A partir desse enfoque, visa-se levantar questões acerca da complexidade e totalidade do tema, ainda que sem respostas definitivas.

O presente artigo representa um esforço para conjugar pesquisa empírica e análise teórica a respeito do que se encontrou nos dados, a partir do campo do Direito. O extenso levantamento de dados, analisados de maneira a evidenciarem, por si, elementos jurídicos relevantes, constituiu uma tentativa de observação descolada, num primeiro momento e na medida do possível, das produções teóricas já existentes. Buscou-se, a partir de um problema concreto acerca de questões de moradia no Brasil, identificar uma das formas com que o Estado lida com tais relações sociais.

A pesquisa realiza a análise das decisões com base na teoria fundamentada nos dados (CHARMAZ, 2009; GIBBS, 2009; STRAUSS; CORBIN, 2008). A finalidade em usar tal metodologia é de construir uma visão mais ligada aos dados e menos influenciada pelos referenciais e esquemas teóricos previamente estabelecidos em pesquisas anteriores. Constitui-se uma tentativa de deixar que os dados apresentem elementos de conexão entre si, na busca de identificação de padrões e teorias explicativas.

Na primeira parte do trabalho, é apresentado um panorama da realidade desigual de estruturação das cidades no território brasileiro. Tal processo pode ser caracterizado por elevada concentração de renda (MEDEIROS, 2015), de propriedade (CALIXTRE, 2014) e de desigualdade na distribuição dos espaços (MARICATO, 2000, 2003; ROLNIK; KLINK, 2011). Esses desarranjos sociais apresentam como resultado conflitos sociais entre aqueles se beneficiam economicamente do desenvolvimento urbano e aqueles que são prejudicados ou não incluídos nesse modelo. Surgem, com isso, organizações e movimentos sociais que buscam fazer frente a esses processos que afastam as pessoas do direito à cidade.

Um dos reflexos dessas formas de contestação do desenvolvimento urbano desigual é a ocupação de áreas ociosas por movimentos sociais. A ocupação é feita tanto para que as pessoas de fato ocupem o lugar, conferindo-lhe função social, quanto como forma de denúncia dessa mesma estrutura que não garante acesso ao direito à moradia e à cidade a todas as pessoas. 
Entretanto, essa forma de luta por direitos encontra resistência de proprietários e esses conflitos, em geral, são levados ao Poder Judiciário para que seja dada uma resposta.

Na segunda parte, é trabalhado o eixo central explicativo da pesquisa, definidor do marco teórico e que tem como ponto de partida a análise dos dados. A partir do desvelamento do tema dominante nas decisões, foi possível estabelecer, no campo do direito, a literatura que tratava da temática, desde autores(as) teóricos(as) a pesquisas acadêmicas empíricas. Por fim, delineia-se uma forma de entender o Direito e as relações sociais a partir do caso concreto das ações de reintegração de posse contra o Movimento dos Trabalhadores Sem Teto.

$\mathrm{Na}$ terceira parte, de análise de dados, a presente pesquisa está desenvolvida tendo como unidade de análise as decisões de reintegração de posse contra o Movimento dos Trabalhadores Sem Teto, desde a publicação do Estatuto da Cidade, em 2001, até 2014. Ao longo do trabalho está explicitado, em mais detalhes, o caminho percorrido até que se tivessem tais decisões como objeto de estudo. Adianta-se, entretanto, que tal objeto pode ser interessante para entender como o Poder Judiciário, poder de Estado, analisa tais questões.

\section{CIDADE: DESENVOLVIMENTO DE QUESTÕES HABITACIONAIS}

Os caminhos a serem percorridos antes da pesquisa empírica e no seu decorrer identificam o terreno em que localiza o pesquisador, suas origens e o campo de debates em que pretende se inserir. Nesta parte, serão delineadas as fronteiras do conhecimento jurídico - que demanda uma análise concreta transdisciplinar - em que se inserem o desenvolvimento urbano, os movimentos sociais e o Poder Judiciário. Também será apresentada a origem da pesquisa e seus caminhos metodológicos, com a proposta de abertura para a validação dos achados na pesquisa.

O presente trabalho se encontra inserido neste universo de pesquisa do direito à cidade, que pretende desenvolver o conceito de direito à cidade a partir de sua formulação atual no Brasil e que possui inúmeras diferenças intraterritoriais, mas que, em geral, passou (e passa) por processo recente e acelerado de urbanização. Henri Lefebvre apresentou os contornos internacionais desse debate caracterizando o direito à cidade como "direito à vida urbana" (LEFEBVRE, 2008, p. 118). Para o autor, está presente na cidade a priorização de seu valor de uso, sendo a cidade caracterização de bem supremo entre os bens, a base prática para a realização sensível da vida urbana.

Revista de Direito da Cidade, vol. 08, no 4. ISSN 2317-7721 pp. 1824 - 18671828 
Além disso, o direito à cidade constitui a relação das pessoas com o local em que vivem. Ele está, segundo David Harvey, além do direito de acesso àquilo que já existe, sendo também a possibilidade de construção da cidade a partir dos desejos e vontades das pessoas. Segundo o autor, a liberdade que se tem de se fazer e refazer, assim como a cidade, "é um dos mais preciosos, ainda que dos mais negligenciados, dos nossos direitos humanos" (HARVEY, 2009, p. 9).

\section{MOVIMENTOS SOCIAIS URBANOS E O MTST}

Nesse contexto de urbanização, precarização da vida nas cidades, periferização e gentrificação, os movimentos sociais urbanos se fortalecem com a pauta principal de acesso à cidade, que não se restringe a uma casa, mas também a toda infraestrutura necessária e oferta de serviços públicos. As pessoas integrantes desses movimentos "reivindicam para si o direito de serem reconhecidas como moradoras da mesma metrópole e rejeitam as tentativas de serem ignorados ou mesmo criminalizados" (CASSAB, 2010, p. 59).

O principal componente dessa demanda e de desencadeamento desses processos de descontentamento está na falta de acesso a habitações de qualidade. O déficit habitacional vem sendo calculado, no Brasil, pela Fundação João Pinheiro (2015). O conceito trabalhado pela fundação de déficit habitacional tem relação direta com as deficiências do estoque de moradias. Segundo seu relatório (FUNDAÇÃO JOÃO PINHEIRO, 2015, p. 18), o déficit habitacional

Engloba aquelas sem condições de serem habitadas em razão da precariedade das construções ou do desgaste da estrutura física e que por isso devem ser repostas. Inclui ainda a necessidade de incremento do estoque em função da coabitação familiar forçada (famílias que pretendem constituir um domicilio unifamiliar), dos moradores de baixa renda com dificuldades de pagar aluguel e dos que vivem em casas e apartamentos alugados com grande densidade. Inclui-se ainda nessa rubrica a moradia em imóveis e locais com fins não residenciais.

Segundo a Fundação João Pinheiro, o déficit habitacional no Brasil, em 2012, era de 5,430 milhões de domicílios, sendo que 4,664 milhões (85,9\%) estava constituído em áreas urbanas (FUNDAÇÃO JOÃO PINHEIRO, 2015, p. 31). Em 2007, a estimativa de déficit habitacional no Brasil era de 5,855 milhões de domicílios. Essa queda não alterou a divisão relativa do déficit entre as áreas metropolitanas e as demais áreas. Por outro lado, houve um aumento de concentração do déficit habitacional nas áreas urbanas. Em 2007, 82,5\% do total do déficit habitacional estava 
localizado em área urbana, em comparação a 85,9\% em 2012 (FUNDAÇÃO JOÃO PINHEIRO, 2015, p. 97).

Vale ressaltar que o gasto excessivo com aluguel foi o item com maior crescimento na constituição do déficit habitacional. Em 2007, o componente com maior influência sobre o déficit habitacional era a coabitação familiar (42,4\%), seguido pelo ônus excessivo com aluguel (29,8\%). Já em 2012, o gasto excessivo com aluguel passa a ser o elemento mais importante, responsável por 42,5\% do déficit, seguido pela coabitação familiar, com 34,4\% (FUNDAÇÃO JOÃO PINHEIRO, 2015, p. 97). Esse padrão de aumento tem provável relação com os processos de valorização excessivo dos imóveis nos últimos anos, com efeitos diretos sobre os preços dos aluguéis.

Outro dado levantado pela Fundação João Pinheiro é a quantidade de domicílios vagos, no período de 2007 a 2012. Em 2007, o Brasil apresentava 7,075 milhões de unidades vazias, sendo que 1,835 milhão estavam localizados em regiões metropolitanas. Já em 2012, o número de domicílios vagos subiu para 7,198 milhões, dos quais 1,709 milhão, em regiões metropolitanas (FUNDAÇÃO JOÃO PINHEIRO, 2015, p. 105). Esses dados são indício de que os processos especulativos se mantêm e de que pode haver grande parte dessas habitações descumpridoras da função social da propriedade, nos termos que serão trabalhados mais à frente.

Dentro do espectro dos movimentos sociais urbanos, o Movimento dos Trabalhadores Sem Teto (MTST) apresentou grande crescimento nos recentes anos, tanto em número de pessoas quanto em regiões e Estados brasileiros. Atualmente, o MTST está presente em 11 Estados e no Distrito Federal ao mesmo tempo em que tenta consolidar uma linha nacional de atuação.

A organização coletiva do movimento (LIMA, 2014), suas formas de atuação perante as instituições do Estado (ELIAS, 2014), sua atuação enquanto sujeito coletivo de direitos (MARTINS, 2015) e sua postura frente ao sistema de organização social capitalista (GOULART, 2011) já foram temas de outros trabalhos acadêmicos. Aqui, serão levantados apenas algumas questões organizativas do Movimento, em documentos elaborados pelo próprio MTST e seus militantes, com o objetivo de explicitar a maneira com que a própria organização se coloca diante do cenário acima delineado.

O MTST, segundo Guilherme Boulos (2012, p. 44), é constituído por trabalhadores(as) formais e informais, subempregados(as) e desempregados(as), para fazer lutar pelo direito à moradia e à cidade. É preciso, com isso, superar o estigma de que pessoas sem teto são apenas 
pessoas em situação extrema pobreza e miséria na rua. Apesar destas pessoas demandarem atenção estatal dada situação de vulnerabilidade, essa visão restrita desconsidera a dimensão do problema da falta de habitação ou de sua precariedade para pessoas trabalhadoras que vivem, normalmente, na informalidade, sem direitos assegurados (BOULOS, 2012, p. 14). Diante desse quadro de flexibilização do trabalho, o MTST passou a organizar as pessoas com base no território (MOVIMENTO DOS TRABALHADORES SEM TETO, [s.d.], p. 2).

O movimento desenvolve sua luta adotando o discurso do direito à cidade e a tática de "construir grandes ocupações em terrenos vazios nas periferias urbanas, buscando, com isso, integrar a luta por moradia com a luta por serviços e infraestrutura nos bairros mais pobres" (BOULOS, 2012, p. 48). Segundo Cassab, esse ato de ocupar está na base organizativa do movimento e é a exteriorização do seu processo de luta (CASSAB, 2010, p. 50). Essa forma, segundo Miguel Baldez (1989), tem como principal característica a forma coletiva, fora dos padrões individualistas tradicionais do direito.

Esse resumido panorama acerca do MTST foi necessário para compreender seu desenvolvimento, sua estratégia de luta e seus objetivos a serem alcançados. Sua tática de ocupação será o objeto de análise na presente pesquisa a partir de sua judicialização pelo proprietário da área. Avalia-se que esse momento de conflito é capaz de explicitar algumas questões e padrões acerca da atuação do Poder Judiciário enquanto função do Estado e a forma adotada para resolver esse conflito coletivo sobre questões urbanas e de moradia.

\section{CAMINHOS DA PESQUISA}

Para a realização dessa análise, foram levantadas todas as ações judiciais de primeira instância que envolviam o Movimento e/ou suas lideranças. A restrição às decisões de primeira instância foi feita porque se trata do grau de jurisdição originário para todas as ações de reintegração de posse contra o MTST e que apresentam relação direta com sua atuação. Aliado a isso, existiram questões de ordem prática que dificultaram a análise: as decisões em segunda instância foram difíceis de encontrar, seja por falta de informação no processo originário acerca do número do agravo de instrumento, seja porque, em decisão processual de segunda instância, já havia desfecho da questão social, sem novas informações ao processo.

Revista de Direito da Cidade, vol. 08, no 4. ISSN 2317-7721 pp. 1824 - $1867 \quad 1831$ 
A pesquisa dos processos judiciais foi realizada por meio dos sítios eletrônicos dos Tribunais de Justiça dos Estados onde o Movimento dos Trabalhadores Sem Teto desenvolvia suas ações até o final do ano de 2014. Também foram feitas buscas nos sítios dos Tribunais Regionais Federais e das respectivas seções judiciárias dos mesmos Estados. As buscas foram guiadas a partir de palavras-chave e nomes das lideranças locais do MTST, utilizando os sistemas de consulta processual e de consulta de jurisprudência.

Desse modo, ao total, foram encontrados registros de 50 ações de reintegração de posse contra o Movimento dos Trabalhadores Sem Teto no período analisado. Desse total, cinco ações não apresentaram documentos nos sítios dos tribunais (uma em Minas Gerais, duas em Pernambuco e duas em São Paulo), provavelmente por se tratarem de processos mais antigos, já que são todos de 2003. Não foi possível sequer saber se houve medida de reintegração de posse. Havia certeza apenas quanto ao polo passivo ser o MTST.

Houve também duas ações contra o Movimento em Minas Gerais, uma com decisão de reintegração de posse e outra sem a ordenação de reintegração de posse. Essas informações foram possíveis pela referência às decisões nos andamentos processuais, disponíveis no menu de consulta. Entretanto, as decisões integrais não constavam disponíveis digitalmente, o que inviabilizou o uso dos dados.

Ainda, em 11 processos, não houve decisão que determinasse judicialmente a reintegração de posse, seja por meio de medida liminar, seja por meio sentença até o final do ano de 2014. Desse modo, essas decisões não fazem parte do universo de análise uma vez que interessa à pesquisa analisar as motivações para o deferimento judicial da reintegração de posse. Isso se deu porque os processos foram extintos antes de qualquer pronunciamento decisório por conta do magistrado ou porque apenas as decisões judiciais não são suficientes para dar conta dos desdobramentos do caso.

Das ações judiciais em que não houve decisão para reintegração de posse, uma (TO 5008895-42.2013.827.2729) apresenta o processo suspenso por depender de decisão e julgamento em outro processo, conforme art. 265 do Código de Processo Civil. Três processos (SP 2014 0006801-53.2014.8.26.0191; SP 2014 1007373-47.2014.8.26.0011 e SP 2013 400378542.2013.8.26.0002) foram extintos sem resolução de mérito por conta de desistência da parte 
autora. Já a ação MG 0534325-81.2013.8.13.0702 foi extinta sem resolução de mérito por falta de pressupostos processuais e de condições da ação.

Outra causa para a inexistência de decisão para reintegração de posse foi a realização de acordo, em audiência de conciliação, entre o autor da ação, o Movimento e órgãos do governo. Tal fato ocorreu em quatro processos, todos casos de São Paulo (0015733-63.2013.4.03.6100; 1007542-74.2014.8.26.0127; 1035086-65.2014.8.26.0053 e 4004396-92.2013.8.26.0002). elemento comum a todos os processos é que o acordo sempre veio acompanhado de compromisso do MTST em desocupar a área.

Por fim, em apenas dois casos houve indeferimento, por questões de mérito, da medida liminar. Na ação PE 0032835-05.2014.8.17.0001, por não haver demonstração do autor sobre sua propriedade, já que há dúvida acerca da titularidade da área em conflito com propriedade da União. No processo PE 0049640-72.2010.8.17.0001, foi indeferida a liminar em primeira instância, porque o autor não comprovou o exercício da posse, com posterior deferimento da reintegração de posse em Agravo de Instrumento, julgado em segunda instância.

Diante disso, o universo de análise da presente pesquisa está constituído de 32 processos de primeira instância que apresentaram decisão de reintegração de posse contra o Movimento dos Trabalhadores Sem Teto. As análises abaixo foram feitas com base nas decisões liminares e nas sentenças de mérito, conforme disponibilidade pública e eletrônica. Pretende-se, com esse conjunto de dados, construir teoria a partir de uma análise qualitativa.

\section{Metodologia de Análise}

O presente trabalho se desenvolveu a partir da análise qualitativa dos dados. O que se objetivou com esse modelo foi uma visão detalhada dos dados, buscando identificar minúcias e singularidades com base em comparações sistemáticas entre os dados. A partir da metodologia de análise qualitativa adotada na presente pesquisa, objetivou-se teorizar com base no que os dados trazem de conteúdo, ao passo que se tem como meta não se ater à mera descrição da realidade, mas sim à construção de uma cadeia de relações, visões de mundo e formas de ação concreta dos sujeitos da pesquisa.

Para isso, foi escolhida a metodologia da teoria fundamentada nos dados (grounded theory), uma vez que ela permitiu o entendimento da forma decisória de expressão judicial a partir 
do que a decisão, por si mesma, propõe. Isso foi desenvolvido com base no pressuposto de que os dados, trabalhados por meio de combinações específicas, podem gerar, por si só, temas a serem abordados em conjunto, superando o simples teste de teorias específicas (GIBBS, 2009, p. 71). Esse expediente de pesquisa deve ser feito a despeito de levantamento prévio de referencial teórico.

O presente trabalho buscou analisar todas as ações de reintegração de posse contra o Movimento dos Trabalhadores Sem Teto (MTST) no período de 2001 (promulgação do Estatuto das Cidades) ao de 2014 (último ano antes do início da escrita do trabalho). Com isso, abriu-se a possibilidade de investigar o tratamento do Poder Judiciário ao Movimento em seis Estados, oferecendo maiores elementos para uma investigação mais ampla desse próprio Poder. Vale chamar a atenção de que não se trata de uma busca por generalizações, mas de uma visão ampla da realidade pesquisada.

Visou-se, neste trabalho, empreender uma abordagem analítica, mediante comparações e confrontos dos dados coletados de maneira a esgotar, dentro dos limites financeiros e temporais, o universo de ações de reintegração de posse contra o MTST. É o que Strauss e Corbin (2008, p. 24) chamam de "dados qualitativos quantificados". Em suas palavras, a pesquisa persegue o "processo não-matemático de interpretação, feito com o objetivo de descobrir conceitos e relações nos dados brutos e de organizar esses conceitos e relações em um esquema explanatório teórico" (STRAUSS; CORBIN, 2008, p. 24).

Assim, a análise qualitativa foi realizada por meio de avaliações recíprocas entre as categorias analíticas construídas a partir das decisões. Com essas avaliações, foi possível analisar propriedades e dimensões dos dados, escapando da mera descrição. O objetivo foi o de construir relações entre os códigos que superem uma análise superficial, normalmente baseada no arcabouço teórico trazido pela experiência do pesquisador (STRAUSS; CORBIN, 2008, p. 88). Para operacionalizar esses procedimentos, foi utilizado o programa de análise qualitativa de dados denominado MAXQDA: Qualitative Data Analysis Software ${ }^{3}$.

Os códigos relacionados às decisões foram construídos a partir do uso recorrente do gerúndio, que possibilita uma perspectiva de ação e de continuidade nos dados das decisões (CHARMAZ, 2009, p. 76). Sem esse passo metodológico, aumentam-se as possibilidades de

3 Esse programa permite realizar comparações, imputar códigos aos trechos das decisões, elaborar memorandos, gerar tabelas, fazer comparações e etc. Mais informações sobre as características estão disponíveis no sítio do fornecedor: < http://www.maxqda.com/>.

Revista de Direito da Cidade, vol. 08, no 4. ISSN 2317-7721 pp. 1824 - $1867 \quad 1834$ 
direcionamento dos dados rumo às visões do pesquisador. Iniciou-se por uma análise linha a linha (STRAUSS; CORBIN, 2008, p. 67), para gerar os primeiros códigos. Em seguida, realizou-se uma hierarquização dos códigos, com o objetivo de agrupar os que apresentam propriedades e dimensões semelhantes, para posterior comparação sistemática (GIBBS, 2009, pp. 98-9).

Para que se faça uma análise mais teórica das decisões judiciais, busca-se a análise de especificidades dos casos que tenham possibilidade de aplicações em outros casos. Segundo Strauss e Corbin (STRAUSS; CORBIN, 2008, p. 92), trata-se de passar do específico ao geral, com maior poder de análise. Não se teve como objetivo a descoberta apenas de questões individuais das decisões, porque poderiam levar a simples descrições casuísticas elegidas por preconcepções trazidas da literatura específica da área.

Para o desenvolvimento da capacidade indutiva dos dados, é necessário fazer perguntas constantes às decisões, na busca de reflexões ainda não realizadas acerca dos dados e, por outro, desenvolver comparações constantes. Com isso, as diversas categorias e trechos das decisões foram submetidos a variadas comparações entre itens frequentes nos dados com categorias diversas, tendo como pano de fundo a experiência do pesquisador e as teorias levantadas na literatura (STRAUSS; CORBIN, 2008, p. 92).

Essa técnica foi utilizada para que se conseguisse sair da tensão descritiva e passasse para uma atividade mais analítica dos dados, buscando, a partir das decisões, desenvolver teoria. As diferentes formas de codificação dos dados (aberta, axial e seletiva) foram realizadas para que fosse identificada a categoria teórica fundamental para a análise dos dados, representativa, de maneira ampla, de todas as decisões. Tal categoria principal serviu de base para o levantamento da literatura e do referencial teórico adotado no trabalho.

\section{DIREITO ABSOLUTO À PROPRIEDADE: BALIZA NORMATIVA DOS DADOS}

A partir da análise dos dados a ser demonstrada na terceira parte, foi feito um levantamento acerca do conceito chave com que os magistrados trabalham a questão central identificada nas decisões: o direito absoluto à propriedade. Os desdobramentos e contrapontos ao direito de propriedade também foram analisados: função social da propriedade, posse, direito à moradia e o que se entende por Direito. Buscou-se, com isso, avaliar a relação entre a literatura

Revista de Direito da Cidade, vol. 08, no 4. ISSN 2317-7721 pp. 1824 - 18671835 
jurídica, teoria do Direito e a prática dos tribunais referente à aparente dicotomia entre o direito de propriedade e o direito à moradia.

A propriedade é campo de debates e de análise social em vários ramos das ciências sociais e aplicadas. No Direito, suas conceituações e categorizações são variadas e apresentam múltiplas facetas a partir do direito positivo, da literatura jurídica ou mesmo da jurisprudência. Entretanto, as discussões a respeito desse tema e seus correlatos (posse e função social) precisam superar o debate dogmático, porque, como já alertava Fachin (1988, p. 11), não dão conta da complexidade das relações sociais em estudo.

O entendimento da propriedade varia, por um lado, acerca da determinação de seu conteúdo enquanto direito real, cujos debates se dão em torno de qual seria o objeto da propriedade e qual seria sua amplitude; por outro lado, o debate se dá pela extensão da propriedade e pela proteção de seu uso, de sua utilidade, por meio das faculdades de usar, gozar e dispor, protegendo-a de quem a detenha injustamente (FACHIN, 1987, p. 34).

Carlos Frederico Marés analisa a evolução da propriedade rural e sua mudança no capitalismo de maneira a compreender a propriedade urbana e como ela se tornou sinônimo de liberdade. Segundo Marés, antes do tratamento moderno da propriedade individual da terra, seu uso era determinante, isto é, para que alguém fosse considerado proprietário, deveria utilizá-la. Foi a modernidade capitalista que possibilitou que alguém pudesse possuir uma terra como mercadoria, individual e transferível a quem não usa (MARÉS, 2010, p. 182). Então, para reverter essa obrigação de uso, os juristas liberais passaram a entender que qualquer intromissão na propriedade por parte do Estado seria restritiva da liberdade do proprietário. (MARÉS, 2010, p. 182).

Com isso, o direito construído a partir da visão liberal individualista trata a propriedade como um poder jurídico e absoluto sobre um bem como possibilidade de uso restrito ao seu titular (COMPARATO, 1997, p. 93). Porém, a propriedade passa a ser protegida não apenas como relação da pessoa com uma coisa, mas como a proteção e garantia da liberdade. Proteger a propriedade passa a ser significado de liberdade de uma pessoa em relação às demais e ao Estado, tornando-se necessária a institucionalização desse conceito jurídico: reconhece-se o direito individual à liberdade e o instituto jurídico da propriedade (COMPARATO, 1997, p. 94).

Revista de Direito da Cidade, vol. 08, no 4. ISSN 2317-7721 pp. 1824 - 18671836 
Ao lado desse direito puro subjetivo, constitui-se uma necessidade de conceituação abstrata da propriedade, capaz de abranger todos os tipos de propriedade, possuídas por um sujeito de direito também abstrato e formal. Com isso, cabe ao proprietário exercer seu direito como the aprouver. Isso, segundo Eroulths Cortiano Junior, constitui o binômio sujeito geral e abstrato e modelo de propriedade único e universal, ambos entendidos na lógica da neutralidade jurídica (CORTIANO JUNIOR, 2002, p. 112-3). Com isso, qualquer pessoa pode ser merecedora de proteção, desde que proprietária (CORTIANO JUNIOR, 2002, p. 116).

A conceituação da propriedade a partir do paradigma individualista como direito subjetivo personalizado vem, entretanto, sofrendo algumas tentativas de flexibilização. Segundo Fredie Didier Jr, a propriedade, historicamente defendida como garantia de liberdade humana, configura-se mais propriamente, dadas as desigualdades sociais, instrumento de exercício de poder sobre outrem. Diante disso, é necessário reconhecer que a propriedade também obriga, gerando um poder-dever que se relacione ao lado passivo dos direitos humanos alheios (DIDIER JR, 2008, p.6).

Gustavo Tepedino defende que o direito à propriedade não apresenta mais caráter absoluto, mas um conteúdo limitado por "interesses extraproprietários, os quais vão ser regulados no âmbito da relação jurídica de propriedade" (TEPEDINO, 2004, p. 317). Desenvolve-se, assim, com a Constituição Federal de 1988, o contorno da "propriedade constitucional", que não é a redução do conteúdo da propriedade, mas uma relação jurídica envolvida com interesses não proprietários. "Assim considerada, a propriedade (deixa de ser uma ameaça e) transforma-se em instrumento para realização do projeto constitucional" (TEPEDINO, 2004, p. 323).

Essas alterações, segundo Gustavo Tepedino, se dão, no caso brasileiro, de maneira dependente do fenômeno constitucional da função social da propriedade, que modificara a conceituação vigente à época do Código Civil de 1916 (TEPEDINO, 2004, p. 321). A despeito de toda a literatura identificar uma nova configuração da constituição normativa do direito à propriedade, não foi isso o encontrado nas decisões judiciais. Ainda se identifica, pela análise das decisões, a configuração de um direito à propriedade absoluto, aos modos tradicionais liberais. Há pouco espaço para discussão normativa a respeito do que é abstratamente previsto pelo ordenamento jurídico e para a análise detalhada e concreta da configuração proprietária nos casos em análise, como se verá também pelas poucas referências acerca da função social da propriedade. 


\section{FUNÇÃO SOCIAL DA PROPRIEDADE}

Da mesma forma que a conceituação da propriedade apresenta divergência, a maneira com que se reconhece juridicamente seu uso varia conforme a importância para o direito de propriedade. Seu principal exemplo se dá a partir da ideia de que uma propriedade precisa cumprir uma função social, em contraponto ao uso absoluto e indiscriminado. Como direito em si, a propriedade se configura como absoluta e erga omnes, porém a forma como esse direito é exercido encontra barreiras sociais ligadas ao bem-estar da coletividade.

Segundo Edésio Fernandes (2002, p. 14), foi a Constituição Federal de 1988 quem desenhou uma formulação consistente à função social da propriedade urbana. Segundo o autor, essa fórmula pode ser assim sistematizada: "o direito de propriedade imobiliária urbana é assegurado desde que cumprida sua função social, que por sua vez é aquela determinada pela legislação urbanística, sobretudo no contexto municipal” (FERNANDES, 2002, p. 14).

Em relação à propriedade urbana, há dependência do que vem determinado nos Planos Diretores dos Municípios. Entretanto, Henrique Frota defende que as leis municipais não apresentam autonomia absoluta quando da determinação da função social. Há uma série de elementos a serem considerados em consonância com as diretrizes da política urbana, em especial o atendimento às demandas por moradia urbana digna, proteção ao meio ambiente, combate à especulação imobiliária e o adequado desenvolvimento do espaço urbano (FROTA, 2015, p. 47). Luiz Edson Fachin defende como principal desdobramento da função social a perda de proteção possessória constitucional à propriedade que não cumpre sua função social (FACHIN, 2009, p. 280).

Há, por isso, autores que defendem que a função social da propriedade deve ser avaliada quando da análise das ações reintegratórias de posse (DANTAS, 2013; FERREIRA, 2015). Anderson Schreiber também faz análise de decisões judiciais para defender que os tribunais brasileiros vêm apresentando ampla aplicação do princípio da função social da propriedade "como critério qualificativo da conduta do proprietário em face dos interesses sociais e dos valores constitucionais envolvidos" (SCHREIBER, 2000, p. 28). O autor junta alguns exemplos dessa aplicação entre os quais: a) o Supremo Tribunal Federal, que disse que uma propriedade não cumpre a função social 
quando desrespeita normas municipais de caráter urbanístico; e b) o Tribunal de Justiça do Rio Grande do Sul, que considerou que uma propriedade rural que apresenta débitos de natureza fiscal, ainda que produtiva, também descumpre a função social (SCHREIBER, 2000, pp. 11-2).

Para além dessa forma tradicional, a dogmática jurídica trata a função social de maneira bastante diversa. A função social da propriedade tem relação direta com o exercício da posse, segundo Fredie Didier Jr (2008, p. 2), que considera a comprovação do exercício da função social como elemento indispensável à proteção da posse. Para o jurista, função social e direito de propriedade, que poderiam, em tese, ser vistos como antitéticos, apresentam caráter complementar. Só haveria, dessa maneira, direito à propriedade se seu exercício se desse em correlação com sua função social.

Seguindo nessa linha, Alfonsin estende o problema do não reconhecimento das implicações sociais, aos não proprietários, da propriedade urbana e rural que não cumpre a função social a limitações dos intérpretes das leis e do fato de que são, provavelmente, influenciados pelo lugar social que ocupam (ALFONSIN, 2006, p. 176). Esse posicionamento dos magistrados vem, em geral, acompanhado da responsabilização exclusiva do Estado acerca das questões sociais de falta de terra e moradia, como notado na presente pesquisa. Sobre isso, Alfonsin contrapõe-se com o argumento de que a função social da posse e da propriedade não pode ser pensada sem referência à eficácia horizontal dos direitos humanos fundamentais (ALFONSIN, 2006, p. 177).

Diante do quadro apresentado de ineficácia das normas referentes à função social da propriedade, Alfonsin já chama a atenção para a existência de elementos que vão além da eficácia da norma. A legislação não é a responsável pela desigualdade na distribuição da terra no país. Percebe-se, outrossim, que a posição do intérprete, como parece ser o caso nos dados analisados, está retirando a eficácia da função social expressamente previstas, até mesmo "pelas formas de seu uso que o direito de propriedade permite" (ALFONSIN, 2006, p. 186-7).

Como se verá na análise dos dados tendo por base o superficial tratamento do instituto da função social da propriedade nos processos judiciais, esse tema parece ser defeso à análise judicial concreta. Como elemento constitutivo do direito de propriedade determinando constitucionalmente, sua desconsideração se coaduna com o tratamento absolutizado do direito à propriedade. O que se defende nos autos não é o direito à propriedade vigente, mas o ilimitado e intangível. 


\section{POSSE}

A discussão acerca da posse constituir questão autônoma ou não em relação à propriedade constitui também tema de controvérsias acadêmicas. Segundo Fachin, a visão predominante seria a de que a posse seria mera exteriorização da propriedade, o que consitui uma visão superada pela realidade concreta. Para o autor, a posse, enquanto conceito autônomo, deve ser considerada um direito. Isso porque a posse não é parte do conteúdo da propriedade, mas sim sua causa, porque sua fonte histórica e sua necessidade, sob pena de recair sobre o bem uma força aquisitiva (1988, p. 13).

Ana Rita Vieira de Albuquerque, em direção semelhante, pondera que, embora a posse tenha orientação voltada para a propriedade, aquela não pode se restringir a esta. Essa visão, segundo a autora, se confirma pelo próprio desenvolvimento social dos países colonizados, em que a posse surge antes como categoria autônoma, demandante de proteção por si mesma e não como proteção reflexa da propriedade. A autora completa que "tanto a importância como a independência da posse em relação ao direito de propriedade vêm ainda determinada por sua função social" (ALBUQUERQUE, 2002, p. 94-5).

Teori Albino Zavascki defende a tese de que deve ser superada, no debate jurídico brasileiro, a noção de que a posse se caracteriza como mero desdobramento da propriedade (2004, p. 8). Apesar de o direito à posse não estar normatizado explicitamente na Constituição Federal, a "disciplina da posse, e a correspondente tutela jurídica, se dá implícita e indiretamente, na medida e em consideração àquilo que ela representa como concretização do princípio da função social das propriedades" (ZAVASCKI, 2004, p. 11).

Diante disso, a posse, porque diz respeito ao efetivo uso dos bens, tem relação com comportamento das pessoas, proprietários e não proprietários, que detêm o poder fático sobre o bem. Seria, assim, "um princípio que se dirige ao possuidor, independentemente do título da sua posse" (ZAVASCKI, 2004, p. 11). Com isso, o autor conclui que o princípio da "função social das propriedades" (ZAVASCKI, 2004, p.24) diz "respeito mais ao fenômeno possessório do que ao direito de propriedade" (ZAVASCKI, 2004, p. 8).

Revista de Direito da Cidade, vol. 08, no 4. ISSN 2317-7721 pp. 1824 - $1867 \quad 1840$ 
Diante disso, Antonio Ferreira assevera que a legislação processual brasileira não apresenta técnica adequada para tratar conflitos fundiários de natureza coletiva. Não há, desse modo, distinção procedimental entre as ações de caráter individual e as de caráter coletivo, o que, segundo o autor, enseja violação de direitos humanos, especialmente direito à moradia (FERREIRA, 2015, p. 93-4). Esse entendimento parece também aplicável às questões abordadas nos processos sob análise, onde ausente a preocupação com elementos procedimentais que deem conta da complexidade social da demanda por moradia.

\section{DIREITO À MORADIA}

O Direito à moradia, garantido no artigo 6o da Constituição Federal, está previsto em diversos tratados internacionais e é trabalhado sobre variadas matizes no âmbito jurídico (ABREU, 2011; SARLET, 2009; SAULE JÚNIOR; LIBÓRIO; AURELLI, 2009). Ingo Wolfgang Sarlet afirma que o direito à moradia tem caráter de direito humano (expresso em tratados internacionais, com amplo reconhecimento) e de direito fundamental (de caráter nacional, referente à hierarquia constitucional). Diante disso, o autor afirma que o direito à moradia apresenta dupla proteção normativa, geradora de garantia a todas as pessoas, dada sua fundamentalidade e relação com a dignidade humana (SARLET, 2009, p. 4).

Após a inserção explícita do direito à moradia no texto constitucional brasileiro, houve uma progressiva ramificação legislativa desse direito nas normas infraconstitucionais, o que fortaleceu seu discurso normativo (ABREU, 2011, p. 395). Segundo Abreu, uma decorrência disso é que esse direito não fica dependente apenas da legalidade, isto é, se desenvolve de maneira relativamente autônoma, independentemente de se tratar de aquisição contratual de propriedade, de locação, de loteamento irregular ou de ocupação de áreas públicas ou privadas. A legitimidade deve ser analisada no caso concreto, tendo em vista todas suas peculiaridades, sem desconsideração de seu caráter normativo (ABREU, 2011, p. 397).

O fato do direito à moradia estar garantido constitucionalmente, entretanto, não estabeleceu muitos elementos para que a realidade habitacional no Brasil mude. Em contrapartida, a ocupação ilegal, segundo Ermínia Maricato, foi e continua sendo o carro chefe do desenvolvimento urbano no Brasil. Com isso, a ocupação de áreas de interesse ambiental ou de áreas públicas se tornou comum nas grandes cidades e não representa de fato uma forma de

Revista de Direito da Cidade, vol. 08, no 4. ISSN 2317-7721 pp. 1824 - $1867 \quad 1841$ 
respeito ao direito à moradia ou aos direitos humanos. Além do comprometimento ambiental, normalmente são áreas sem nenhuma cobertura de serviços urbanos básicos, como saneamento básico e energia elétrica. (MARICATO, 2003, p. 158).

\section{QUAL DIREITO?}

A pesquisa, uma vez localizada no campo do Direito, demanda uma visão do que se entende por Direito como baliza científica para o campo de debates acerca dos dados coletados e das análises estabelecidas.

A análise das decisões e a constatação da defesa da propriedade como argumento explícito e motivação implícita não estariam totalmente representadas no campo do conhecimento jurídico se apenas as normas estatais fossem levadas em consideração. O resgate histórico da primeira parte do texto já trouxe a avaliação da cidade dividida em duas: uma parte cumpridora da lei, porque acessível às classes mais ricas, e outra forjada na irregularidade, com uma ausência essencialmente de acesso à moradia, seja por falhas no mercado imobiliário, seja por falhas nos sistemas estatais de provisão habitacional.

Essa mesma ilegalidade, que constituiu parte considerável do desenvolvimento urbano, andou de mãos dadas à disputa por um direito à moradia e à cidade àquelas pessoas exploradas em sua força de trabalho e sem habitação em condições dignas. Surgem as formas de luta por acesso à cidade, com reivindicações reconhecidas por parte do direito estatal, mas repetidamente violadas pelo mercado e pelo Estado. Pensar o ordenamento jurídico como norma estatal, garantidora da coesão social, não explica suficientemente a complexidade do problema aqui analisado.

Em relação ao tema da pesquisa, as formas de manutenção da proteção do proprietário de maneira absoluta e incondicionada derivam, segundo Luiz Edson Fachin, de uma construção histórica de perpetuação de interesses dos titulares da propriedade e do poder. Para o autor, "os senhores do século XIX talham instrumentos para manter sua posição de primazia" (2009, p. 279). No campo do Direito, os cursos são oferecidos, em regra, para fornecer o arcabouço teórico e prático de que necessitam esses senhores territoriais.

A questão de fundo encontrada nos processos diz respeito diretamente a uma visão dogmática do direito restrita à conceituação absoluta de propriedade. Não se trata de visão restrita 
ao positivismo, afinal direito à moradia e função social da propriedade estão previstos no ordenamento jurídico brasileiro, já que a propriedade também não é absoluta, como levantado acima pela literatura jurídica. O esquema positivo qualifica enquanto propriedade aquela que cumpre uma função social. Diante disso, é necessário entender quais elementos distorcem o Direito.

Luiz Edson Fachin justifica essa diretriz concreta a partir do momento em que as posições jurídicas passam a ser dependentes da integração dos sujeitos no universo das titularidades. Isso faz com que, segundo o autor, o sistema jurídico passe a ser, em vez de um sistema de igualdade e liberdade, um sistema de exclusão desses que não se encaixam na moldura da titularidade. Para Fachin, isso configura uma "história de ausência [...] daqueles que não portam convites ao ingresso das titularidades de direitos e obrigações" (FACHIN, 2001, p. 32-3).

Para ir além do debate acerca do positivismo, Roberto Lyra Filho desenvolve o conceito de Direito e Antidireito. Segundo o autor, o poder burguês consegue se manter e proteger próprios interesses a partir desses dogmas intangíveis. Isso acontece "mesmo quando contradições da superestrutura levam a doutrina, a jurisprudência ou até a lei a dar certa flexibilidade ao esquema jurídico-positivo, de toda sorte permanece dentro do marco infraestrutural do modo de produção capitalista" (LYRA FILHO, 1980, p. 24).

Segundo Roberto Lyra Filho, Direito e Antidireito estão abrangidos, em maior ou menor grau no corpo normativo. O primeiro é o "Direito propriamente dito, reto e correto, e [o segundo] negação do Direito, entortado pelos interesses classísticos e caprichos continuístas do poder estabelecido" (LYRA FILHO, 2004, p. 8). Isso se dá porque, segundo o autor, o Direito autêntico expressa princípios e normas libertadores, em que a lei pode indicar, ou não, as melhores conquistas (LYRA FILHO, 2004, p. 10).

O que parece estar em jogo nas ações de reintegração de posse é que, a despeito de toda normatização e positivação, tanto no âmbito nacional quanto no âmbito internacional, do direito à moradia e da solidificação normativa da função social da propriedade, ainda não se tem espaço para a efetivação concreta desses avanços. Isso porque essas alterações se dão dentro de uma organização institucional comprometida com interesses sociais dominantes, de defesa da propriedade absoluta. Nesse caso, o sistema absorve apenas uma quota de mudança que não produza alterações substanciais e radicais (LYRA FILHO, 2004, p. 69). 
Assim, o que ocorre, segundo Roberto Lyra Filho, é uma dominação contraditória, porque há uma absorção do discurso da liberdade (no caso em análise, do direito à moradia e da função social da propriedade), mas uma negação na prática concreta. Se, por um lado, é uma confirmação, ainda que retórica, de direitos conquistados (a que o opressor não pode mais negar), por outro, o que se faz é entortá-lo, separando discurso e ação (LYRA FILHO, 2004, p. 84).

Todo esse arcabouço teórico leva a crer que a luta por direitos não se encerra na positivação e que esta não garante efetividade. O que essas lutas de movimentos sociais organizados busca alcançar é que se dê concretude ao direito à moradia e à função social da propriedade, sistematicamente negados pelo Poder Executivo e pelo Poder Judiciário. A chave para entender esses processos parece estar localizada além do espectro do Poder Judiciário, que se constitui, nos casos em análise, como instrumento de manutenção e defesa de interesses proprietários

\section{ANÁLISE DOS DADOS}

A análise fundamentada dos dados foi realizada a partir da codificação axial, necessária para identificação da categoria teórica central, que é aquela capaz de guiar o esquema teórico dominante já trabalhado e, a partir do refinamento da teoria, explicar a dinâmica da maioria dos casos (STRAUSS; CORBIN, 2008, pp. 155-7). Num primeiro momento, foram levantados 70 códigos, divididos em seis categorias analíticas irmãs: "decisão - exercício do poder judicial"; "fundamentos da decisão"; "interferências externas ao processo"; "lei e legislação"; "Movimento Social"; e "questões processuais", nem todas trabalhadas no presente artigo.

Essas categorias possibilitaram a realização de comparações sistemáticas entre si e entre seus códigos-filhos, cujo eixo central se reportava, sistematicamente, ao direito de propriedade e seus desdobramentos. A análise dessas comparações foi feita a partir da reflexão sobre esses mesmos códigos combinada com transcrições de trechos das decisões. Pretende-se levantar os elementos mais sintomáticos das temáticas abordadas a partir das questões e expressões concretas sob estudo.

Diante disso, passar-se-á à análise dos dados tendo como balizadores questões pertinentes ao direito de propriedade já comentadas. As questões encontradas nos processos estão organizadas a partir de linhas de argumentação dos magistrados e formas de apresentação e 
construção das decisões, tendo por base os códigos de pesquisa. Para facilitar o entendimento, a avaliação dos dados está feita por divisão em tópicos condizentes com as categorias analíticas e sub-tópicos teórico-analíticos.

\section{FUNDAMENTOS DA DECISÃO}

Nessa categoria analítica, foram agregados todos dados e informações considerados de caráter argumentativo da decisão. Foram elencados elementos que formam, em tese, o convencimento do magistrado de que a medida de reintegração de posse deve ser determinada. É a categoria que mais colaciona elementos ligados à categoria analítica central de proteção do direito à propriedade e que serviu de direcionamento para a revisão bibliográfica e referencial teórico.

Para a quantificação das ações, foram calculadas porcentagens de repetição dos códigos e questões encontradas nos processos. As porcentagens estão referenciadas no universo de 32 decisões analisadas e, em situações distintas desse universo, as porcentagens estão devidamente explicadas. Já para facilitar a referências aos processos, estes foram organizadas a partir do Estado, ano da ação e os quatros primeiros números (ou cinco, caso haja repetição dos demais dados) do processo de acordo com a numeração única do Conselho Nacional de Justiça. Assim, a título de exemplo, a ação de reintegração de posse no 0014753-38.2005.8.17.0001 do Estado de Pernambuco será denominada simplesmente de "PE 2005 0014".

\section{Proprietário}

O primeiro elemento a chamar a atenção nos processos é o destaque constante da parte autora como proprietária, sob o ponto de vista da legalidade necessária para o desenrolar da ação judicial. Em 18 processos (56,25\%), houve destaque da parte autora como proprietária regular e legítima ou, no mínimo, alienante fiduciária, com a explicação da finalidade de se tornar proprietária. Pelo que se depreende das decisões, há um status privilegiado de quem é proprietário, tornando-se a qualificação central nas ações de reintegração de posse analisadas.

Percebe-se grande variação nas denominações para o proprietário ("dono", "proprietário", "promitente compradora quitada", "legítimo proprietário"), para a propriedade em si ("justo título", 
"propriedade", "matrícula do bem") ou para a situação que envolve autor e objeto da ação ("domínio", "que pertence", "alienação fiduciária"). Todas essas expressões reforçam o caráter dúplice da relação entre o bem e quem exerce seu domínio. Nos processos, constitui uma forma de demarcar a polarização da relação processual e o reconhecimento da parte autora como legítima interessada na reintegração de posse.

Ainda sobre o destaque como proprietário, dois padrões de argumentação puderam ser identificados. Por um lado, em oito $\operatorname{casos}^{4}$, a ocupação do imóvel objeto de reintegração não poderia se dar dessa maneira porque o direito à moradia iria de encontro ao direito de propriedade, que não pode ser violado. Nesse ponto, destaca-se a responsabilidade do Poder Público em resolver a questão social de fundo. Por outro lado, em dez $\operatorname{casos}^{5}$, o magistrado constata o esbulho possessório como questão principal da decisão e não se atine ao conflito de normas constitucionais ou o faz apenas tangencialmente para dizer a responsabilidade do Executivo.

Em relação à forma de reivindicação, o destaque da parte autora como proprietária se relaciona com a afirmação da impossibilidade de sacrifício do direito à propriedade, ainda que haja reivindicação pelo direito à moradia. Tal situação configuraria desrespeito à ordem jurídica. É o que se percebe em trechos como o retirado da ação de reintegração de posse PE 20010001 :

Afirmou a Autora que os Réus ocuparam indevidamente os Lotes 01/20 [...] de sua propriedade. [...]. Por mais que se considere o direito à moradia como um fator de dignidade da pessoa humana, não há como justificá-la ao arrepio do direito de propriedade, igualmente considerado na Carta Constitucional.

Já em relação ao segundo ponto, o destaque como proprietário aparece basicamente como elemento caracterizador da evidência do esbulho. Por outros trechos o seguinte da ação PE 2005 0014: "Outrossim, provado nos autos a propriedade do bem reclamado, conforme documentação acostada aos autos às fls.08/14 nos autos, também, o esbulho possessório praticado pelo réu". Tem-se a reintegração de posse como corolário da comprovação da propriedade e do esbulho possessório no caso em análise, sem referência aos princípios constitucionais.

\footnotetext{
${ }^{4}$ DF 2013 0000; PE 2001 0001; RJ 2014 0057; SP 2007 0002; SP 2007 0004; SP 2008 0002; SP 2008 0012; SP 20130021.

5 PE 2005 0014; PE 2011 0005; PE 2011 00114; RJ 2014 0010; SP 2008 0002; SP 2011 00116; SP 2014 0002; SP 2014 1038; SP 2014 1044; TO 20135003.
} 
A alienação fiduciária como confirmador do caráter de proprietário estabelece, em dois casos, assertivas sobre o cumprimento de funções inerentes ao domínio, portanto exteriorizadores da posse e de sua proteção. Em um dos casos (SP 2014 1008), a alienação de uma fração da propriedade induz o exercício da posse da área remanescente, dada atuação legal do proprietário, em que não houve contestação judicial do próprio processo de alienação. No outro caso (SP 2003 0021), a alienação se deu no curso do processo, configurando elemento de exercício da posse e que mantém a necessidade de proteção judicial mediante ação de reintegração de posse.

\section{Título de propriedade}

Percebe-se das referidas decisões que a alienação remete à propriedade enquanto finalidade em si, ou seja, configura-se dono aquele que apresenta o título de propriedade, formalidade jurídica que origina tal direito. 0 título é utilizado, em sete casos $(21,88 \%)$, como causa jurídica da posse, isto é, a formalidade capaz de constituir alguém proprietário é usada como elemento ensejador da proteção possessória, ainda que sem relação ao contato material direto com o imóvel. Nesses casos, a ligação entre título de propriedade e posse é afirmada de maneira direta.

Na DF 2013 0000, o magistrado afirma que "possuidor, portanto, é quem aparenta ser proprietário, não sendo necessário o contato material com a coisa", o que demonstra a desnecessidade de contato direto. Semelhante fundamentação está presente no caso RJ 2014 0057, cujo imóvel pertence à massa falida de uma sociedade empresarial, que exercia, segundo o magistrado, a posse. Percebe-se aqui uma afirmação sem referência à comprovação de uso da propriedade, especialmente por se tratar de imóvel em litígio sucessório.

Nos outros cinco $\operatorname{casos}^{6}$, a afirmação da posse tem relação direta com o título, que "é exercida presumidamente pelo autor com certidão de matrícula do imóvel" (TO 2013 0053). O mesmo acontece na ação PE 2003 0022, já que o autor, a "CRUZ VERMELHA BRASILEIRA, tem a posse legítima do imóvel objeto dessa ação possessória, decorrente de escritura pública de compra e venda". Nesses casos, a posse do proprietário, mesmo presumida, elide a possível posse do réu que ocupou o terreno.

${ }_{6}^{6}$ PE 2003 0022, PE 2006 0021, RJ 2014 0010, SP 20070004 e TO 20130053. 


\section{Uso da propriedade}

Acrescentando ao destaque da parte autora como proprietária, em cinco casos (15,63\%), é evidente a tentativa do magistrado em justificar o uso da propriedade com base em elementos simples, mas que contrapõem o abandono da propriedade. Os motivos variam entre os de caráter fático atual ("vários motivos podem ter levado a paralisar a obra", na DF 2013 0000; "com projeto para implementação de empreendimento no local", na SP 2014 0002), passado ("a autora já utilizou o terreno como sua própria sede por longo período", na PE 2003 0022; "imóvel em comodato para que uma família próxima exercesse a vigilância", na SP 2008 0002) ou de caráter legal ("a administração tem discricionariedade para utilizar o imóvel público", na SP 2007 0004).

A existência de projetos futuros não executadas por fatores alheios à vontade do proprietário também entra no rol de fundamentações legitimadoras do não uso da propriedade. Sob o ponto de vista utilitarista da declaração de vontade daquele que exerce o domínio, são levantadas circunstâncias impeditivas e nenhuma menção a processos de supervalorização ou especulação com o terreno. Essa menção a projetos futuros aparece em seis casos $(18,75 \%)$ e constitui argumento aos reclames dos ocupantes por se tratar de área abandonada.

Em quatro dos $\operatorname{casos}^{7}$, a afirmação de projetos futuros se refere ao uso econômico estrito da área, afirmando que o local servirá como base para futuro empreendimento comercial. Para esses casos, há a discriminação das ações que já foram realizadas pelos proprietários. No caso DF 2013 0000, o autor "pretende agora construir no local uma instituição de ensino superior", em um "imóvel [que] hoje tem apenas as pilastras e o teto do que seria construído". Ainda como exemplo, na SP 2014 0002, a parte autora:

possui projeto para a construção de empreendimento no local e que está adotando providências, desde meados de 2013, para sua implementação junto à Prefeitura Municipal de São Paulo. Resulta, assim, que, além do domínio da área, comprovou a autora que estava exercendo a posse sobre o bem.

Em outros dois casos, a finalidade futura tem relação com obras de cunho social. Na ação PE 2011 00114, o imóvel servirá para uso como habitação social pelo Município, em que "OS imóveis do autor já têm como destinatários pessoas previamente selecionadas pelo serviço social

\footnotetext{
${ }^{7}$ DF 2013 0000, SP 2003 0021, SP 2013 0021, SP 20140002.
} 
do município". Já na ação PE 2010 0053, o imóvel será utilizado para construção de abrigo para crianças e idosos da comunidade, estando "a área sob exame [...] em vias de expressiva requalificação e destinação social, representada pelo projeto a ser patrocinado pela entidade religiosa denominada Igreja Batista, com o fito de fazer construir a Fundação Sementes de Esperança".

Essas formas anteriormente citadas constituem elementos caracterizadores do não abandono da propriedade. São seguidas, em geral, por argumentação da existência efetiva do esbulho possessório e da impossibilidade de permanência dos ocupantes da área. Tanto os projetos passados quanto os futuros são descritos de maneira superficial e pouco detalhados, mas que servem de base, também, para fundamentação do exercício da posse, ainda que não explicitamente em todos os casos.

Há ainda, em dois casos (6,25\%), o reconhecimento de atividades econômicas no momento contemporâneo da ação judicial, embora elencados de maneira genérica, sem avaliação do andamento das execuções ou dos riscos da ocupação. Em um caso, a autora construiu um galpão para realização de suas atividades, mas não há relato da construção e nem continuidade dessas ações: "a documentação exibida pela autora revela que citado imóvel foi adquirido pela mesma para atender suas atividades comerciais, no qual chegou a instalar, inclusive, um galpão industrial, onde funcionava sua fábrica de caminhões" (SP 2003 0021).

No outro caso, a área ocupada pertence a uma empresa que realiza suas atividades econômicas em outro terreno de sua propriedade ao lado do ocupado, fato que geraria, segundo o magistrado, risco de ocupação da área efetivamente utilizada para as atividades. Segundo o magistrado, "foram ocupados prédios da empresa, próximos à área efetivamente utilizada pela empresa para suas atividades, que também corre risco de ocupação". Tal ocupação ameaça esse prédio próximo, que possui "uso efetivo de parte dela para a atividade empresarial da autora, com equipamentos instalados no local" (RJ 2014 0010).

A preocupação com a vigilância do imóvel também constitui elemento que afirma a não intenção do particular em ver sua propriedade ser apropriada por outro, ainda que para fins de moradia. Essa preocupação aparece expressa em sete dos casos $(21,88 \%)$, seja na forma de vigilância direta do proprietário ou de pessoa por ele designada sem ônus, seja na forma de contratação de equipe profissional de vigilância. A referência à preocupação com a vigilância serve 
como instrumento de confirmação do uso da propriedade e do interesse do proprietário em mantê-la.

Nesse sentido, a vigilância serve como cumprimento de obrigação automática da propriedade, sinônimo de conservação e exteriorização de atos do domínio. Por isso, a constatação do magistrado de que a parte autora "mantinha o imóvel litigioso vigiado" (DF 2013 0000). Isso também se reflete em preocupação momentânea com a vigilância: "além do mais, o registro de ocorrência policial demonstra a prática de ato com a finalidade de defender o seu imóvel da invasão realizada" (TO 2013 5003).

A vigilância é considerada também elemento essencial para o exercício da posse, na forma de um poder-dever intrínseco à propriedade. Isso se dá porque a vigilância garante, segundo o juízo, que os proprietários "exerciam a posse sobre ele (ainda que por intermédio de zelador mantido no local)" (SP 2014 1044). A vigilância também afirma a posse "da autora, pois se trata de área cercada, sob sua vigilância" (RJ 2014 0010), fato reconhecido também pelo membro do Ministério Público, "que [segundo o magistrado] traz relevantes elementos para a formação desta cognição liminar, acrescentando-se ao já esmiuçado a contratação de serviço de vigilância para os imóveis" (SP 2014 1008).

Nas demais situações, a vigilância decorre como elemento do uso da propriedade pelo proprietário ou por terceiros. Pelo proprietário, isso decorre do fato de que o "referido imóvel situa-se em frente ao local onde a demandante está instalada, permitindo-lhe, por isso, a permanente vigilância daquele" (SP 2003 0021). Por terceiros, isso se dá porque, segundo o juízo, o "imóvel estava cedido em comodato a Sra. Cilene da Silva Santos e sua família, a fim de que zelassem e promovessem a guarda do mesmo, em proteção à propriedade da autora" (SP 2008 0002).

\section{Direito à moradia "subordinado concessivo"}

Enquanto em alguns processos, há tratamento dual entre direito à propriedade e direito à moradia do ponto de vista formal, em 11 decisões (34,37\%), há referência expressa ao direito à moradia como direito humano, constituinte da dignidade da pessoa humana. Todavia, esse direito é reconhecido apenas de maneira "subordinada concessiva", isto é, apresenta validade formal até que ele se contraste ao direito à propriedade, à forma jurídica estatal, ao monopólio da violência ou 
ao direito positivado. Por isso, o direito à moradia só poderia ser concedido em detrimento do direito à propriedade de acordo com as próprias flexibilizações e relativizações legais deste.

Nesse ponto, o direito à propriedade, como direito eminentemente individual, representado na ação judicial por um particular isolado não tem estrutura para resolver um problema coletivo, cuja competência de resolução do "drama social" é do Poder Público (PE 2001 0021), "apesar da previsão constitucional do direito social à moradia (art. 60 da CF/88)" (PE 2010 0053). Isso porque o Estado deve ser o responsável, "mesmo a par da questão social que o caso encerra" (TO 2013 5003).

Ademais, o local deve oferecer condições dignas aos demandantes que, caso inexistentes, "submete[m] pessoas que se deslocam para o local a uma situação que afronta à dignidade mínima existencial” (RJ 2014 0057). O contraponto a isso é que qualquer espécie de intervenção nesse direito individual demanda aplicação das medidas constitucionais e legais, sob a supervisão do Poder Judiciário contra violação por parte do próprio Estado ou de outros particulares. Isso porque "o acesso da população carente à moradia, fazendo valer a função social da propriedade, dar-se-á dentro da ordem constitucional e através de institutos legais de intervenção na propriedade privada alheia (usucapião, desapropriação, tratamento fiscal diferenciado etc.)" (PE 2003 0022).

Assim, "por mais que se considere o direito à moradia como um fator de dignidade da pessoa humana" e "por mais legítimos que sejam tais direitos de moradia e trabalho" (PE 2005 0004), não se pode utilizar vias que não sejam previstas no Estado Democrático de Direito, nem violar o direito à propriedade. Mesma argumentação no caso SP 2008 0012, com a concessão "embora seja legitima a luta e a reivindicação por moradia, saúde, transporte, cidadania". Desse modo, por conta dessa violação, "em nada socorre a apelante [MTST], diante disso, invocar em seu favor a função social da propriedade prevista no art. $5^{\circ}$, inc. XXIM, da Constituição Federal" (SP 2003 0021).

Nota-se também, a partir desse direito à moradia concessivo, uma preocupação dos magistrados com a precariedade das ocupações. A precariedade é imputada ora para o movimento social em relação às condições do acampamento e consequente desrespeito à dignidade humana, ora serve estritamente como fundamento para a necessidade da reintegração de posse. Cabe indagar se essa preocupação tem relação com a proteção efetiva do direito à moradia ou do direito à propriedade, cujas fragilidades deste, nos casos concretos, não são levantadas. 


\section{Função Social da Propriedade}

Ainda do ponto de vista da argumentação jurídica, a referência à função social da propriedade aparece explícita em apenas cinco processos (15,63\%). Em três deles (SP 20030021 , PE 20030022 e DF 2013 0000), o comentário sobre a função social se deu após reclame do réu. Em geral, a contestação do réu foi respondida pelo magistrado com a necessidade de ação do Poder Público para, nos termos da lei e da Constituição, realizarem o processo de intervenção na propriedade, caso haja descumprimento.

No caso SP 2003 0021, o magistrado responde à alegação do réu em:

seu favor [d]a função social da propriedade prevista no art. $5^{\circ}$, inc. XXIM (sic), da Constituição Federal, mesmo porque, eventual desatendimento a este princípio constitucional poderia ensejar, quando muito, a desapropriação do imóvel pelo Poder Público Municipal ou pela União, conforme o caso, não dando direito a quem quer que seja invadir a propriedade alheia.

No caso PE 2003 0022, responde ao reclame do imóvel estar abandonado há cinco anos dizendo que fazer "valer a função social da propriedade, dar-se-á dentro da ordem constitucional e através de institutos legais de intervenção na propriedade privada alheia (usucapião, desapropriação, tratamento fiscal diferenciado etc.) ". Na ação DF 2013 0000, "eventual falha da proprietária na atribuição de um destino ao imóvel que permita que ele cumpra a sua função social" deveria seguir o rito do art. 182, § 40 da Constituição Federal.

As afirmações que não constituem resposta ao réu estão presentes em dois casos. No processo SP 2008 0002, há afirmação categórica do magistrado de que há cumprimento da função social ao dizer que "o imóvel objeto da invasão é particular, está situado em área urbana, e cumpre com as funções inerentes da propriedade". Por fim, no processo PE 2001 0021, a afirmação do magistrado de que, quando "a propriedade não atende a função social, a saída é o processo expropriatório".

Acerca da não responsabilidade do particular em relação à demanda de trabalhadores sem teto por moradia, em quatro casos $(12,5 \%)$, há referência à impossibilidade de o indivíduo proprietário lidar com essa questão social, ainda que a parte proprietária apresentasse eventual omissão quanto à propriedade. Em um dos casos, há a afirmação de que tal situação de omissão não deveria ser avaliada no caso em análise e que "eventual omissão do Poder Público ou do 
proprietário, nesse aspecto, não autoriza a invasão do imóvel urbano por terceiros" (DF 2013 0000), cujas medidas de fundo constitucional deveriam ser tomadas pelo Poder Público.

Noutro caso, mesmo que a parte autora tenha demorado a reivindicar a área ocupada (há afirmação da existência de vigilância no local), não teria como consequência a legitimação da posse dos ocupantes, uma vez que "a tolerância no uso do imóvel não implica renúncia nem induz posse" (PE 2003 0022). No caso TO 2013 5003, fica evidente a responsabilidade do Estado em "implementar as políticas públicas necessárias ao atendimento dos anseios destes trabalhadores sem teto, não podendo tal encargo recair sobre os autores". Há isenção de responsabilidade também do Poder Judiciário na ação SP 20070002.

\section{Análise da posse}

Em apenas nove casos (28,13\%), há avaliação específica da posse pelo magistrado, em que busca estabelecer a posse da parte proprietária como fundamento bastante para a negação da posse do movimento réu. Em geral, essa afirmação se dá mais como efeito retórico, isto é, com a simples afirmação do exercício da posse, do que como enumeração dos elementos caracterizadores da posse em si. Ademais, a referência à posse é levantada, nos casos, como requisito necessário para autorização da medida de reintegração de posse.

As formas de justificação da posse variam de acordo com o caso concreto e com o que o magistrado entende por posse. Em alguns casos, ela é entendida como poder de fato referente à utilização econômica do bem. No caso SP 2014 1009, "o elemento substancial seria o interesse, encarnado na posse, em sua configuração econômica de utilização da coisa". Na ação SP 2014 1008 ,

Tal ato implica, notadamente, em disposição de parcela desta posse, bem como em seu efetivo exercício, ainda no interstício em que remanesce defesa eficiente no Juízo Possessório, aqui manejado, não havendo como se presumir, diante do que consta dos autos, ter outrem melhor posse sobre os bens que não a autora.

No processo SP 2003 0021, há semelhante fundamentação ao comentário do juízo que

Vê-se, pois, que tais provas são suficientes para evidenciar que autora adquiriu também a posse desse bem, eis que esta nada mais é do que o modo por que a propriedade é utilizada, a relação de fato estabelecida entre a pessoa e a coisa pelo fim de sua utilização econômica. 
Ainda nesse sentido, no processo RJ 2014 0010, confirma-se "a posse da autora, pois se trata de área cercada, sob sua vigilância, com uso efetivo de parte dela para a atividade empresarial da autora, com equipamentos instalados no local".

Noutros, a demonstração da posse vem intimamente ligada à aquisição do direito de propriedade. No caso SP 2007 0004, "reside a discussão na regularidade ou não da ocupação do imóvel e no direito do réu e demais ocupantes de nele permanecer [uma vez que] ocorre que o referido imóvel possui natureza jurídica de bem público". Na ação RR 2011 0707, isso fica evidente com "os documentos colacionados pelos autores permite a conclusão de que efetivamente adquiriram os direitos de posse sobre o imóvel desde o ano de 2003 e que em maio de 2009 foram esbulhados em sua posse". E, no caso PE 2010 0053, a simples afirmação do magistrado de que "verifico que a parte autora provou quantum satis a sua posse".

A posse também se fundamenta das obrigações decorrentes da propriedade e ao cumprimento de obrigação tributária com o Imposto Predial e Territorial Urbano, uma vez que "os autores, legítimos proprietários e cumpridores de sua obrigação tributária, vez que o IPTU dos lotes está devidamente quitado" (PE 2011 0005). Em um caso ainda há a explicitação da posse como poder de fato, que não demanda contato direto do proprietário com o bem, sendo que "possuidor, portanto, é quem aparenta ser proprietário, não sendo necessário o contato material com a coisa, mas apenas a prática de atos de destinação econômica" (DF 2013 0000).

Alguns magistrados também teceram comentários sobre a ausência de posse do terreno pelos réus. Em nove casos (28,13\%), há justificação explícita para a rápida reintegração de posse do terreno, devido a problemas estruturais do imóvel ou riscos para o autor da ação. No caso SP 2014 1008, "é de se esclarecer que, se acaso se demonstrar que as conclusões aqui alcançadas não são as melhores, seja em termos de fato ou de direito, por seu caráter precário, a liminar concedida poderá ser revista". Nos demais casos, os riscos da manutenção da ocupação se dividem em dois grandes grupos: ambientais e possibilidade de novas invasões. Há, no entendimento dos magistrados, possibilidade de novos cometimentos de ilícitos civis ou penais.

Os riscos ambientais se devem à instabilidade do terreno, "tanto que havia no local placas informativas acerca dessa situação (fls. 30), sem contar que, como dito na inicial, no mesmo local, tempos antes, uma tragédia ocorreu, com a morte de várias pessoas, devido à instabilidade do terreno" (SP 2014 1038). Os riscos se devem também à existência de área verde e cursos de água 
na região, com a "predominância de áreas verdes na região assim como cursos d'água que abastecem a Represa citada" (SP 2007 0002). Ou também, na ação SP 2014 1009: "área invadida está contaminada por produtos tóxicos, e inclusive está interditada pela CETESB".

Há o risco de novas invasões, configuradoras, em tese, de ilícito civil e penal de turbação ou esbulho. Na ação SP 2011 00116, há elementos suficientes no processo, "o que caracteriza in thesi o justo receio da autora de que sofra novos esbulhos ou turbações". E, no processo PE 20100053 , "os réus estariam descumprindo uma tentativa de ocupação pacífica e parcial da área sob foco e avançando sobre o restante do terreno, o que reforça o risco de danos à parte promovente".

Os perigos constatados também são de deterioração do bem. Por esse, a ação SP 2011 00112, "além do perigo de deterioração da propriedade e dos bens nela constantes acaso o provimento jurisdicional seja dado apenas na fase final deste procedimento". Há também iminência de crime ambiental, pois "Há predominância de áreas verdes na região assim como cursos d'água [...]. Desta forma, a ocupação desordenada pelos requeridos e centenas de outras famílias configuraria em até crime contra a legislação do meio ambiente” (SP 2007 0002).

Há também um caso em que há o relato do imóvel ser residência da autora, no qual "o tipo de esbulho verificado neste caso justifica a urgência da medida, uma vez que o imóvel é a residência da autora" (RR 2011 0707) ainda que as duas autoras da ação sejam empresas do ramo imobiliário. Por fim, na ação PE 2011 00114, os imóveis já estariam destinados à habitação pelo serviço social do Município, de onde decorre que a ocupação em "relação a ditos bens poderá provocar danos de ordem social e até mesmo de natureza material".

\section{LEI E LEGISLAÇÃO}

A segunda categoria-mãe sob análise será a denominada "lei e legislação". Nessa categoria, foram elencados todos trechos das decisões em que havia referência à lei, à justiça, ao direito e à legalidade. Por se tratarem de elementos constantes nos discursos e decisões judiciais e por representarem o arcabouço normativo estatal balizador da ação de reintegração de posse, buscavase encontrar indicações da forma de tratamento do direito e das normas jurídicas a partir da judicialização das ocupações do Movimento dos Trabalhadores Sem Teto.

O primeiro elemento a ser analisado é a legalidade do ponto de vista da obediência à legislação, seja no caso concreto, seja como imperativo ao magistrado. Por se tratar de um Poder 
de Estado que se pauta pelo cumprimento da lei, é esperado que se invoque a legislação como balizador da decisão. Entretanto, a norma jurídica escolhida pelo juízo pode ser colocada como balizador intransponível e irrefutável determinante de sua decisão. Isso apresenta uma intencionalidade evidente a partir do momento em que se elege determinada norma em detrimento do restante do corpo normativo.

A necessidade de obediência à legislação apareceu em 18 processos (56,25\%), variando entre a simples referência à lei e a análise do conflito de normas no caso concreto. Percebeu-se, nesse tópico, quatro grandes ramos de justificação, que, em tese, retirariam a possibilidade do magistrado em decidir de outra forma: defesa da propriedade; qualquer interferência na propriedade deve ser legal; a forma de ação do movimento social é ilegal e inconstitucional; e as questões processuais devem ser tratadas do ponto de vista da lei. Algumas decisões contemplam mais de um ramo.

Em relação à defesa da propriedade, as referências à legislação variam entre o cumprimento de procedimento legal destinado à proteção da posse e da propriedade e a argumentação de que quaisquer outros valores sociais e jurídicos a serem protegidos devem ser deixados em segundo plano na análise concreta. Em quatro $\operatorname{casos}^{8}$, tem-se como pressuposta a cristalinidade da legislação no sentido de promover a proteção da posse e da propriedade, violada por terceiros, numa análise meramente formal.

Na ação SP 2007 0002, o magistrado aduz que "o ordenamento jurídico protege os direitos de domínio e posse de imóveis por particulares ou mesmo pelo Poder Público" e que "este Juízo apenas cumpre a lei e não dispõe de local para abrigar os ocupantes". A posse do autor deve ser protegida no caso SP 2014 1008, porque "o ato foi registrado devidamente no Cartório competente, como apontado acima, o que garante, diante da legislação, a publicidade necessária, mesmo que, no mundo materialístico, não tenha havido qualquer exercício de animus domini".

Já em três $\operatorname{casos}^{9}$, o elemento formal de proteção da posse e da propriedade vem combinado com o contraponto fático da impossibilidade de resolução da questão social por meio do Poder Judiciário, e sim pelo Poder Executivo. Na ação PE 2005 0004, o magistrado é categórico nessa análise ao dizer que:

\footnotetext{
8 SP 2007 0002, SP 2014 1008, SP 20141009 e RR 20110707.

${ }^{9}$ PE 2005 0004, PE 20010021 e TO 20135003.
} 
O Poder Judiciário, ao referendar, de alguma forma, tal prática [de fazer valer estes direitos mesmo que à custa de atos arbitrários e violentos], estaria legalizando iniciativas que correspondem a fatos puníveis previstos na legislação penal vigente.

Semelhante postura se encontra no caso PE 2001 0021, quando o magistrado faz uma série de comentários sobre a temática:

Para fazer justiça o Judiciário pode até suprir a lacuna da lei, lapidar as arestas injustas da mesma e emprestar um valor que não se limita à mera redação, mas, definitivamente, não pode negá-la. Nem mesmo em atendimento a regra estampada no art. 5o da LICC, conquanto os fins sociais a que a lei se destina não autorizam a desconsideração das normas de direito privado que atribuem direitos aos cidadãos. De se ressaltar que deferir a posse em favor dos demandados seria praticar o confisco que, por razões óbvias, fere a lei, o direito e a justiça. [...] circunstância que não deixa outra alternativa, senão o acolhimento do pedido ora examinado.

Há, ainda, em dois casos, a referência normativa abstrata do necessário cumprimento da lei, não só porque há proteção legislativa à posse e à propriedade, como também porque se trata de lei a ser cumprida. Na ação PE 2003 0022, isso é reforçado nos trechos: “A ordem jurídica garante ao legítimo possuidor o direito de ser restituído na posse no caso de esbulho" e "[...] o Poder Judiciário deve, sem qualquer proselitismo político-ideológico, garantir a tutela judicial de proteção à posse ou propriedade". No processo TO 2014 0021, cabe o magistrado decidir conforme a lei, ainda que dura: "Cabe então ao julgador a luz dos preceitos legais e dos elementos carreados para aos autos aplicar a lei ainda que seja amargo o sabor da medida".

A respeito da interferência legal na propriedade, os casos se dividem entre a impossibilidade de uso do imóvel na forma como se encontra, porque devem seguir legislação específica para seu uso, e o necessário procedimento legal para intervenção no direito de propriedade. Em dois casos, os imóveis são públicos e qualquer forma de uso deve ser disciplinada por lei. No processo SP 2007 0004, "estes [os louváveis argumentos do réu] não são suficientes para alterar as normas legais que regulam o tema em questão e não o desobrigam de deixar o imóvel após requerimento de seu legítimo titular". Enquanto na ação SP 2014 1038:

Esclareço, a propósito, que a destinação pública do bem objeto desta demanda não permite que ele seja utilizado para fins outros que não os previstos expressamente em lei. Em assim sendo, a ocupação pelos integrantes do movimento réu, porquanto não previsto em lei, mostra-se abusivo e passível de proteção pela via eleita. 
Nos outros três ${ }^{10}$, os magistrados afirmam a inexistência de fundamento legal para a intervenção na propriedade na forma em análise no caso concreto. Para a ação PE 20010021 , "deferir a posse em favor dos demandados seria praticar o confisco que, por razões óbvias, fere a lei, o direito e a justiça". Na ação SP 2014 0002, para o magistrado, "não há fundamento legal para a revogação da liminar concedida". E na ação DF 2013 0000, eventual descumprimento da função social "pode acarretar as medidas previstas no art. 182, § 4으, da Constituição Federal de 1988 (parcelamento ou edificação compulsórios, IPTU progressivo no tempo e desapropriação), cabendo ao Poder Público a sua adoção, nos termos da lei".

Sobre a forma de ação do movimento social ser ilegal e inconstitucional, há um grande enfoque ao descumprimento da legislação a partir da forma de intervenção direta adotada pelo MTST. Em quatro casos, a ocupação do imóvel escapa da legalidade e compromete qualquer reivindicação legítima do Movimento. Na ação SP 2003 0021, o magistrado deixa isso claro no trecho: "quem, portanto, desrespeitou, no caso vertente, o princípio da legalidade não foi a autora, como afirma a apelante, mas sim esta e o próprio Movimento que diz participar".

No processo PE 2005 0004, o magistrado tenta fazer diferenciação de outras ações de reintegração de posse ao dizer que:

Aqui a situação é diferente. A ocupação constatada foge a este padrão de "normalidade", chegando a configurar um trabalho sistemático e programado de uma organização criada para a reivindicação de teto e terra para moradia e trabalho, no intuito de fazer valer estes direitos mesmo que à custa de atos arbitrários e violentos.

Na ação SP 2008 0002, isso se reflete no fato de que "não se pode admitir que os objetivos do movimento sejam buscados por meio de violência, em manifesta afronta à ordem jurídica e ao Estado Democrático de Direito". E, no processo SP 2008 0012, a violação é ao "princípio básico de qualquer estado democrático de Direito o respeito às leis e Constituição vigentes.

Já no caso RJ 2014 0057, há uma ligeira diferença em relação aos quatro casos anteriores: a situação de ilegalidade se dá na perpetuação do Movimento Social no imóvel, o que não pode ser permitido. Assim, segundo o magistrado, a "reintegração de posse seja o mais rapidamente cumprida, sob pena de se perpetuar uma situação que escapa da legalidade". Tais elementos já demonstram uma forma de alguns magistrados em entender a ação do MTST, questões que serão trabalhadas mais abaixo.

${ }^{10}$ PE 2001 0021, SP 20140002 e DF 20130000. 
Por fim, o cumprimento estrito da legislação demanda o devido tratamento às questões processuais, com a imposição das sanções processuais ao réu ausente, onde o magistrado "conhecerá diretamente do pedido, proferindo sentença, é o que prescreve o art. 330, II, do CPC" (PE 2001 0001). Ou, de modo contrário, se a tutela da posse deve ser realizada com base na lei, esta pode ser relativizada no caso concreto para que a citação seja feita apenas aos líderes do movimento e não a todos integrantes: "tem-se que no caso de esbulho coletivo, promovido por movimento organizado, basta a citação dos seus líderes para a completa integralização da relação processual" (PE 2003 0022).

Assim, tais elementos apresentam uma visão específica de qual legislação deve ser cumprida à risca de maneira concreta e qual deve ser relativizada e sopesada. Na mesma linha, como desdobramento do cumprimento inafastável da legislação, em três processos $(9,38 \%)$, podese notar que o direito à propriedade, ainda que não cabalmente ancorado na legislação, mostra-se plausivelmente sujeito à proteção pelo Poder Judiciário. Nessas três ações ${ }^{11}$, o simples indício de plausibilidade do direito faz com que o magistrado entenda correta a reintegração do autor na posse. A justificativa para a decisão é dada pela possibilidade de reversibilidade da liminar, requisito básico para uma decisão provisória.

\section{FINALIZANDO A ANÁLISE}

A extensão da análise dos dados demonstra uma gama de detalhes, nuances e estruturas que constroem a complexidade da forma como o Poder Judiciário lida com os conflitos fundiários urbanos protagonizados pelo Movimento dos Trabalhadores Sem Teto. Buscou-se uma análise pormenorizada, complementada com trechos das decisões para possibilitar ao(à) leitor(a) um contato mais direto com o universo dos dados. Dada a extensão, alguns códigos de menor potencial explicativo foram retirados da análise.

Ainda que as referências à propriedade sejam variadas no texto constitucional, a prática jurisprudencial em análise não demonstrou que se trata de um debate realizado quando das decisões. O "direito à moradia concessivo" demonstra que a propriedade, ao menos de caráter urbano, está restrita a uma fundamentação individualista, cujo direito fundamental à propriedade

\footnotetext{
${ }^{11}$ PE 2001 0001, SP 201100112 e TO 20135003.
} 
se desenrola de maneira absoluta. Esse fenômeno levanta dúvidas acerca da eficácia normativa da pluralidade de leituras do direito à propriedade a partir de uma visão pluralista e condizente com a chamada "despatrimonialização" do Direito Civil (PINHEIRO; VAZ, 2011, p. 144).

Edésio Fernandes afirma que, apesar de toda inovação legislativa recente, os juristas brasileiros continuam adotando, em geral, posturas liberais individualistas sobre a propriedade. Essa postura, segundo o autor, tem servido a "interesses econômicos que veem nas cidades tão somente o palco da acumulação do capital, sem preocupação com outros interesses sociais e ambientais na utilização do solo urbano" (FERNANDES, 2002, p. 17).

Porém, depreende-se da análise que as questões aprofundam essa característica e que o silêncio das decisões sobre a função social da propriedade, elemento legitimador do uso, talvez ocorra porque esse não é um debate realizado pelos magistrados e tem relação apenas indireta com as formas prévias de aquisição da propriedade. Como, nas decisões, se debatem mais as questões referentes à propriedade, há aqui uma possível motivação para que haja mais referências à alienação do que à função social da propriedade. Deixa-se de lado o debate acerca da posse, para concentrar-se na proteção da propriedade.

O que se depreende do todo levantado é que a linha de proteção da propriedade identificada nos casos em análise diz respeito à manutenção do paradigma absoluto do direito de propriedade. Não se trata de reconhecer um direito à moradia ou uma função social da propriedade acima e além da lei. Estes estão normatizados. O que se percebe é que a aplicação mínima dos institutos legais é desconsiderada diante da manutenção desse paradigma da propriedade absoluta.

\section{CONSIDERAÇÕES FINAIS}

A tônica dos achados da pesquisa está definida em uma passagem do processo PE 2005 0004: "ao contrário, cabe a este Poder [Judiciário], garantir a inviolabilidade do direito à propriedade". Conforme os dados levantados, a proteção da propriedade é o elemento central das ações de reintegração de posse analisadas. Em jogo, estava o direito do proprietário de ser protegido contra qualquer tipo de violação externa às suas faculdades de uso, legítimos ou não, já que essa foi uma variável pouco levada em consideração pelos magistrados. Protegia-se o objeto da propriedade em si, bem como suas faculdades relativas à aquisição da propriedade, mas pouca ou

Revista de Direito da Cidade, vol. 08, no 4. ISSN 2317-7721 pp. 1824 - 18671860 
nenhuma atenção ao seu uso e seus deveres. Enfim, protegia-se a propriedade absoluta liberal ao lado da violação dos princípios constitucionais de direito à moradia e função social da propriedade.

Percebeu-se que os processos não dão conta da complexidade dos conflitos em julgamento, seja porque não trabalham temas constitucionais de direito à moradia e função social da propriedade, seja porque não há tentativas significativas, por parte dos magistrados, de usar formas alternativas e mais eficientes de resolvê-los. Constata-se que há um completo descarte e desproteção do interesse social e da função social do bem em favorecimento ao proprietário individual.

Também a partir das decisões analisadas, identificou-se um padrão de decidir que embasa o entendimento destas como fatores protetores da propriedade e afirmadores da visão de um Poder Judiciário restrito ao conflito que se faz parecer entre indivíduos. Há poucos episódios de preocupação com questões substanciais do conflito e com o caráter coletivo das ocupações.

O que se depreende dos dados é que o Poder Judiciário trata de maneira coletiva apenas as questões socialmente negativas: a falta de moradia é questão do Poder Público e não do particular. Já os benefícios da propriedade, ainda que não cumpra mandamentos constitucionais, é questão individual que não compete a esse Poder fiscalizar. A partir dessa visão, ao Judiciário não cabe intervir em questões coletivas, mas sim garantir a proteção do indivíduo proprietário. É a constatação de que essa maneira de organização institucional ainda está comprometida com a proteção de interesses de classes dominantes.

Como as questões de moradia não podem ser respondidas pelo particular, está aí o argumento formal e abstrato de defesa absoluta da propriedade. É a liberdade individual a ser protegida no caso concreto. Protege-se apenas o sujeito de direitos abstrato e formal. Olvida-se de responsabilidades e ônus do proprietário. Sua única relativização é por meio de punição estatal (desapropriação e instrumentos do Estatuto da Cidade), que demanda processo específico com garantias próprias, desconectadas da ação de reintegração de posse.

Nesse sentido, várias são as hipóteses de proteção da propriedade. Na comparação com outros princípios constitucionais, trata-se de direito fundamental inviolável. Por se tratar de esbulho possessório, não há resposta jurídica válida diversa da reintegração de posse. O uso da propriedade é presumível ante o título cartorial. Esse uso também não precisa ser concreto, bastando a intencionalidade de ações futuras. Se essas ações não estiverem previstas, basta que se 
vigie o bem. Tudo confirmado a partir de uma legitimação inquestionada do discurso da parte autora.

Nas decisões, o direito de propriedade é protegido em seu sentido abstrato e formal, não sendo permitida, no caso concreto, sua violação e, na visão dos magistrados, a consequente violação ao Estado Democrático de Direito. Raras são, entretanto, as fundamentações da posse em diretrizes constitucionais, apesar de se tratar de uma ação que versa sobre esse conceito jurídico. Já o direito à moradia é apenas tratado em seu sentido abstrato e geral que, no caso concreto em análise, não apresenta relevância.

Se, do lado do autor, pleiteia-se a defesa da propriedade, do lado do MTST está o pedido de cumprimento da função social. Esta constitui reivindicação constante dos movimentos sociais, argumento que se fortalece com a situação de falta de habitação, de um lado, e de propriedades abandonadas e descumpridoras da sua função social de outro. Nos casos em análise, a avaliação acerca da função social da propriedade foi, nas três ocasiões em que aparece como como reivindicação social do movimento social, negada. Mas, afirmada como cumprida pelo proprietário, de maneira implícita ou explícita. Percebe-se uma seletividade em direção à proteção excessiva de direitos patrimoniais. O Poder Judiciário viola a lei constitucional para defender a propriedade liberal.

Desse modo, pelo que foi encontrado nos processos, não se pode dizer que a análise da função social não é realizada, mas, na mesma linha do estudo de Marcus Dantas (DANTAS, 2013), só se fala nesse tema para legitimar o uso da propriedade, como também alerta Luiz Edson Fachin (FACHIN, 1988). Esse achados contradizem as reflexões de Anderson Schreiber (SCHREIBER, 2000), que afirma que o Poder Judiciário brasileiro já vinha se adaptando, à época do trabalho do autor, a reconhecer a função social da propriedade a partir de interesses sociais. Não é isso que vem acontecendo em primeira instância em relação ao MTST.

O direito à moradia apareceu em um número maior de decisões (11), como decorrência da dignidade da pessoa humana, o que denota uma maior sensibilidade aos magistrados por esse tema. Entretanto, esse direito é reconhecido apenas de maneira "subordinada concessiva", isto é, apresenta validade abstrata e formal até que se contraste ao direito à propriedade, à forma jurídica, ao monopólio estatal da violência ou ao direito positivado parcial, entortado.

Revista de Direito da Cidade, vol. 08, no 4. ISSN 2317-7721 pp. 1824 - 18671862 
As ocupações urbanas não são invenções de movimentos sociais e organizações de esquerda. Elas constituem a forma que os pobres encontraram para atendimento da necessidade básica de moradia, não atendida pelo Estado e, tampouco, pelo mercado imobiliário (MARICATO, 2003). Não fosse essa ocupação irregular da cidade, os conflitos sociais se dariam de forma mais explícita. Entretanto, os movimentos sociais urbanos organizados surgem como forma de resistência a esse processo ilegal do ponto de vista normativo estatal e violador de direitos humanos. Para isso, usam táticas de denúncia da desigualdade de propriedade e dos abusos proprietários do mercado imobiliário.

Por outro lado, como se percebe do resgate acerca da formação da cidade, a visão restrita do Direito às normas não dá conta de explicar esse fenômeno. Não é simplesmente considerando a cidade ilegal que as questões sociais são explicadas, tampouco solucionadas. Constatou-se, ademais, da análise dos dados, que a aplicabilidade seletiva da legislação constrói um padrão jurídico argumentativo que, por incompleto, gera representações de antidireito.

O rigor da lei se mostra seletivo. Para o proprietário, a lei deve ser rigorosamente cumprida nos casos de desapropriação e de intervenção na propriedade. Já para o preenchimento dos requisitos processuais da ação de reintegração de posse e para o cumprimento da função social da propriedade, flexibilizações são aceitáveis. Para o MTST, a aplicação seletiva da legislação é feita para obriga-lo a desocupar o imóvel, porém não seguida para suas garantias de defesa processual, para o cumprimento do direito à moradia ou exercício da função social.

Por fim, apesar da defesa da propriedade ser o ponto central nas decisões, o que há de diferente nessas ocupações? Por que, em se tratando de movimentos sociais, há repressão do Estado e rejeição às suas formas coletivas de reivindicação por parte do Poder Judiciário? Uma resposta possível é que esses movimentos sociais organizados colocam em xeque a propriedade urbana absoluta. Denunciam a concentração de riqueza, o domínio de um mercado imobiliário especulativo que gera periferização das cidades e "expulsão" de pobres para áreas cada vez mais distantes e menos provida de serviços públicos. 


\section{REFERÊNCIAS}

ABREU, J. M. M. DE. A moradia informal no banco dos réus: discurso normativo e prática judicialRevista DIREITO GV, 28 maio 2011. Disponível em: <http://bibliotecadigital.fgv.br/ojs/index.php/revdireitogv/article/view/23955>. Acesso em: 7 nov. 2015

Construção histórica do modelo proprietário no Brasil: apresentação de uma hipótese sobre o direito à moradia / The historical frame of property model in Brazil: a hypothesis about housing rights. Revista Direito e Práxis, v. 5, n. 8, p. 213 - 239, 15 jul. 2014.

ALBUQUERQUE, A. R. V. Da função social da posse e sua conseqüência frente à situação proprietária. Rio de Janeiro: Lumen Juris, 2002.

ALFONSIN, J. T. A função social da posse como pressuposto de licitude ético-jurídica do acesso e da conservaçao do direito à terra. Revista de Direito Agrario, MDA, v. 19, n. 18, p. 173-95, 2006.

BALDEZ, M. L. Sobre o papel do direito na sociedade capitalista: ocupaçoes coletivas: direito insurgente. Petrópolis: Centro de Defesa dos Direitos Humanos, 1989.

BOULOS, G. Por que Ocupamos?: Uma introdução à luta dos sem-teto. São Paulo: Scortecci, 2012.

CALIXTRE, A. B. Nas fronteiras da desigualdade brasileira. São Paulo: Friedrich Ebert Stiftung, 2014. Disponível em: <http://library.fes.de/opus4/frontdoor/index/index/docld/12298>. Acesso em: 3 nov. 2015.

CASSAB, C. O Movimento Social sob as Dinâmicas do Mundo Global: pensando desafios. ACTA GEOGRÁFICA, v. 4, n. 7, p. 47-65, 9 set. 2010.

CHARMAZ, K. A construção da teoria fundamentada: guia prático para análise qualitativa. Traducao Joice Elias Costa. Porto Alegre: Artmed, 2009.

COMPARATO, F. K. Direitos e deveres fundamentais em matéria de propriedade. Revista CEJ, v. 1, n. 3, p. 92-99, 1997.

CORTIANO JUNIOR, E. O discurso jurídico da propriedade e suas rupturas. Rio de Janeiro: Renovar, 2002.

DANTAS, M. E. DE C. Função social na tutela possessória em conflitos fundiários. Revista Direito GV, v. 9, n. 2, p. 465-488, dez. 2013.

DIDIER JR, F. A função social da propriedade e a tutela processual da posse. Regras processuais no Código, p. 17, 2008. 
ELIAS, G. S. Criar poder popular : as relações entre o MTST e o Estado no Distrito Federal. [s.I.] Universidade de Brasília, 1 jun. 2014.

FACHIN, L. E. Da propriedade como conceito jurídico. Revista dos Tribunais, v. 76, n. 621, p. 16 - 39, 1987.

A função social da posse ee propriedade contemporânea: uma perspectiva da usucapião rural. Porto Alegre: Sergio Antonio Fabris, 1988.

Limites e possibilidades do ensino e da pesquisa jurídica repensando paradigmas. Revista Argumenta, v. 1, n. 1, p. 25-34, 2001.

O estatuto constitucional da proteção possessória. In: FARIAS, C. C. DE. (Ed.). . Leituras complementares de Direito Civil: o Direito Civil-Constitucional em concreto. $2^{\text {a }}$. ed. Salvador: Juspodivm, 2009. p. 396.

FERNANDES, E. Do Código Civil ao Estatuto da Cidade: algumas notas sobre a trajetória do direito urbanístico no Brasil. Revista da Faculdade de Direito do Alto Parnaíba, v. 1, n. 5, p. 12-33, 2002.

FERREIRA, A. R. M. Tutela possessória e a remoção forçada de grupos vulneráveis e famílias de baixa renda. Revista Eletrônica de Direito Processual, v. 14, n. 1, p. 82-107, 2015.

FROTA, H. B. A Função Social Da Posse Como Parâmetro Para Tratamento Dos Conflitos Fundiários Urbanos. Revista FIDES, v. 6, n. 1, p. 37-52, 19 maio 2015.

FUNDAÇÃO JOÃO PINHEIRO. Déficit Habitacional no Brasil 2011-2012. Belo Horizonte: Fundação João Pinheiro - Centro de Estatísticas e Informações, 2015. Disponível em: <http://www.fjp.mg.gov.br/index.php/docman/cei/559-deficit-habitacional-2011-2012/file>. Acesso em: 23 nov. 2015.

GIBBS, G. Análise de dados qualitativos. Traducao Roberto Cataldo Costa. Porto Alegre: Artmed, 2009.

GOULART, D. C. [UNESP]. O anticapitalismo do Movimento dos Trabalhadores Sem-Teto - MTST. [s.I.] Universidade Estadual Paulista (UNESP), 9 ago. 2011.

HARVEY, D. A liberdade da cidade. Tradução de Anselmo Alfredo, Tatiana Schor e Cássio Arruda Boechat. GEOUSP: Espaço e Tempo (Online), n. 26, p. 9-18, 2009.

LEFEBVRE, H. O direito à cidade. Traducao Rubens Eduardo Ferreira Frias. $3^{\text {a }}$ reimper ed. São Paulo: Centauro Editora, 2008.

LIMA, R. L. DE. A emergência do movimento dos trabalhadores sem-teto como novo sujeito coletivo de direitos em Brasília. [s.I.] Universidade de Brasília, 30 jun. 2014.

LYRA FILHO, R. Para um direito sem dogmas. Porto Alegre: Fabris, 1980.

O que é Direito. $10^{\mathrm{a}}$ reimpr ed. São Paulo: Brasiliense - Coleção Primeiros Passos, 2004.

Revista de Direito da Cidade, vol. 08, no 4. ISSN 2317-7721 pp. 1824 - 18671865 
MARÉS, C. Função social da propriedade. In: SONDA, C.; TRAUCZYNSKI, S. C. (Eds.). . Reforma agrária e meio ambiente: teoria e prática no estado do Paraná. Curitiba: Kairós, 2010. p. 181-197.

MARICATO, E. As idéias fora do lugar e o lugar fora das idéias. A cidade do pensamento único: desmanchando consensos. Petrópolis, RJ: Vozes, v. 1, 2000.

Metrópole, legislação e desigualdade. Estudos avançados, v. 17, n. 48, p. 151-166, 2003.

MARTINS, K. F. O direito que nasce da luta : a construção social do direito à moradia e à cidade pelo Movimento dos Trabalhadores Sem Teto no Distrito Federal. [s.l.] Universidade de Brasília, 9 abr. 2015.

MEDEIROS, M. Distribuição da Riqueza no Brasil: Limitações a uma estimativa precisa a partir dos dados tabulados do IRPF disponíveis. SSRN Electronic Journal, 15 ago. 2015.

MOVIMENTO DOS TRABALhAdORES SEM TETO. Cartilha de Princípios, [s.d.]. Disponível em: <http://www.mtst.org/linhaspoliticaseorganizativas.pdf>. Acesso em: 20 nov. 2015

PINHEIRO, R. F.; VAZ, I. DE F. F. Funções sociais das propriedades a realização de direitos fundamentais nas situações proprietárias. Cadernos da Escola de Direito e Relações Internacionais, v. 1, n. 15, p. 120-147, 2011.

ROLNIK, R.; KLINK, J. Crescimento economico e desenvolvimento urbano: por que nossas cidades continuam tão precárias? Novos Estudos-CEBRAP, n. 89, p. 89-109, mar. 2011.

SARLET, I. W. O direito fundamental à moradia na Constituição: algumas anotações a respeito de seu contexto, conteúdo e possível eficácia. Revista Brasileira de Direito Público, v. 1, n. 20, p. 46, 2009.

SAULE JÚNIOR, N.; LIBÓRIO, D.; AURELLI, A. I. Série Pensando o Direito $n^{\circ} 7 / 2009$. Conflitos coletivos sobre a posse e a propriedade urbana e rural - relatório final. Brasília: Ministério da Justiça, Secretaria de Assuntos Legislativos, 2009. Disponível em: <http://www.justica.gov.br/seusdireitos/elaboracao-legislativa/pensando-o-direito/publicacoes/anexos/07pensando_direito.pdf>.

Acesso em: 6 nov. 2015.

SCHREIBER, A. Função Social da Propriedade na Prática Jurisprudencial Brasileira, 2000. Disponível em:

<http://www.andersonschreiber.com.br/downloads/Funcao_Social_da_Propriedade_na_Pratica_J urisprudencial_Brasileira.pdf $>$. Acesso em: 28 out. 2015

STRAUSS, A. L.; CORBIN, J. Pesquisa qualitativa: técnicas e procedimentos para o desenvolvimento de teoria fundamentada. Traducao Luciane de Oliveira Rocha. $2^{a}$. ed. Porto Alegre: Artmed, 2008.

TEPEDINO, G. Contornos Constitucionais da Propriedade Privada. In: TEPEDINO, G. (Ed.). . Temas de Direito Civil. 3. ed. Rio de Janeiro: Renovar, 2004. p. 303-29. 
ZAVASCKI, T. A. A tutela da posse na Constituição e no projeto do Novo Código Civil. Revista Direito e Democracia, v. 5, n. 1, p. 7-28, 2004.

Trabalho enviado em 30 de junho de 2016.

Aceito em 20 de setembro de 2016. 